\title{
A Review on Catalytic Nanomaterials for Volatile Organic Compounds VOC Removal and Their Applications for Healthy Buildings
}

\author{
Kwok Wei Shah ${ }^{*}+\mathbb{C}$ and Wenxin $\mathrm{Li}^{\dagger}$ \\ Department of Building, School of Design and Environment, National University of Singapore, 4 Architecture \\ Drive, Singapore 117566, Singapore; bdglw@nus.edu.sg \\ * Correspondence: bdgskw@nus.edu.sg \\ t These authors contributed equally to this work.
}

Received: 5 May 2019; Accepted: 19 June 2019; Published: 23 June 2019

check for updates

\begin{abstract}
In order to improve the indoor air quality, volatile organic compounds (VOCs) can be removed via an efficient approach by using catalysts. This review proposed a comprehensive summary of various nanomaterials for thermal/photo-catalytic removal of VOCs. These representative materials are mainly categorized as carbon-based and metallic oxides materials, and their morphologies, synthesis techniques, and performances have been explained in detail. To improve the indoor and outdoor air quality, the catalytic nanomaterials can be utilized for emerging building applications such as VOC-reduction coatings, paints, air filters, and construction materials. Due to the characteristics of low cost, non-toxic and high chemical stability, metallic oxides such as $\mathrm{TiO}_{2}$ and $\mathrm{ZnO}$ have been widely investigated for decades and dominate the application market of VOC-removal catalyst in buildings. Since other catalysts also showed brilliant performance and have been theoretically researched, they can be potential candidates for applications in future healthy buildings. This review will contribute to further knowledge and greater potential applications of promising VOC-reducing catalytic nanomaterials on healthier buildings for a better indoor and outdoor environment well-being.
\end{abstract}

Keywords: nanomaterials; VOCs removal; photocatalysis; thermal oxidation; catalytic oxidation; healthy buildings; green application; photocatalytic reactor

\section{Introduction}

Healthy buildings aim to provide a healthy built environment for occupants inside buildings, and indoor air quality can significantly impact occupants' health [1]. Since people spend most of their time inside buildings, indoor air quality has become an increasing concern. Indoor air quality can be affected by various factors including toxicological, microbiological, physical systems, indoor, and outdoor ventilations [2]. The advances in construction technology have produced numerous applications of synthetic building materials, but have also brought some adverse effects on the indoor environment, including the major pollution from volatile organic compounds (VOCs). VOCs are defined as having a boiling point that ranges between $50^{\circ} \mathrm{C}$ and $260^{\circ} \mathrm{C}$ [3]. They can contribute to the formation of ozone and fine particulates in the atmosphere [4] and work directly as toxic substances to the environment and human being. The exposure to VOCs can result in both acute and chronic health effects including respiratory diseases, impaired neurobehavioral function, and sick building syndrome, etc. [2].

In order to remove the VOCs, many methods have been proposed and can be roughly divided into two main groups according to their mechanisms: adsorption techniques and oxidation techniques [5], or the combination of them [6]. The former one is a conventional method by transferring VOCs from the air to the solid phase via adsorbents, e.g., activated carbon [7], biochar [8] and fibre [9], etc. which 
faces challenges like saturation and pore blockages. The latter oxidation techniques provide a better approach to cost-effectively remove VOCs, which show higher degradation activity towards polar VOCs (OVOCs $>$ Ahs $>$ AlHs) [10]. Photo and thermal catalytic oxidation are two of the most common oxidation techniques. Thermal oxidation reactions require a high temperature above $600{ }^{\circ} \mathrm{C}$, and the oxidation efficiency grows with the temperature increase. The technique of photocatalytic oxidation commonly uses nano-semiconductor catalysts and ultraviolet (UV) light to convert organic compounds in indoor air into benign and odourless constituents-water vapor $\left(\mathrm{H}_{2} \mathrm{O}\right)$ and carbon dioxide $\left(\mathrm{CO}_{2}\right)$ for air purification [5,11,12]. Figure 1 shows the basic principle of photocatalytic oxidation for the removal of VOCs. An electron in an electron-filled valence band (VB) is excited by photoirradiation to a vacant conduction band (CB), leaving a positive hole in the VB. Later, the photogenerated electrons and holes can react with $\mathrm{H}_{2} \mathrm{O}$ and $\mathrm{O}_{2}$ molecules to reduce and oxidate VOCs on the surface of a photocatalyst [12-14].

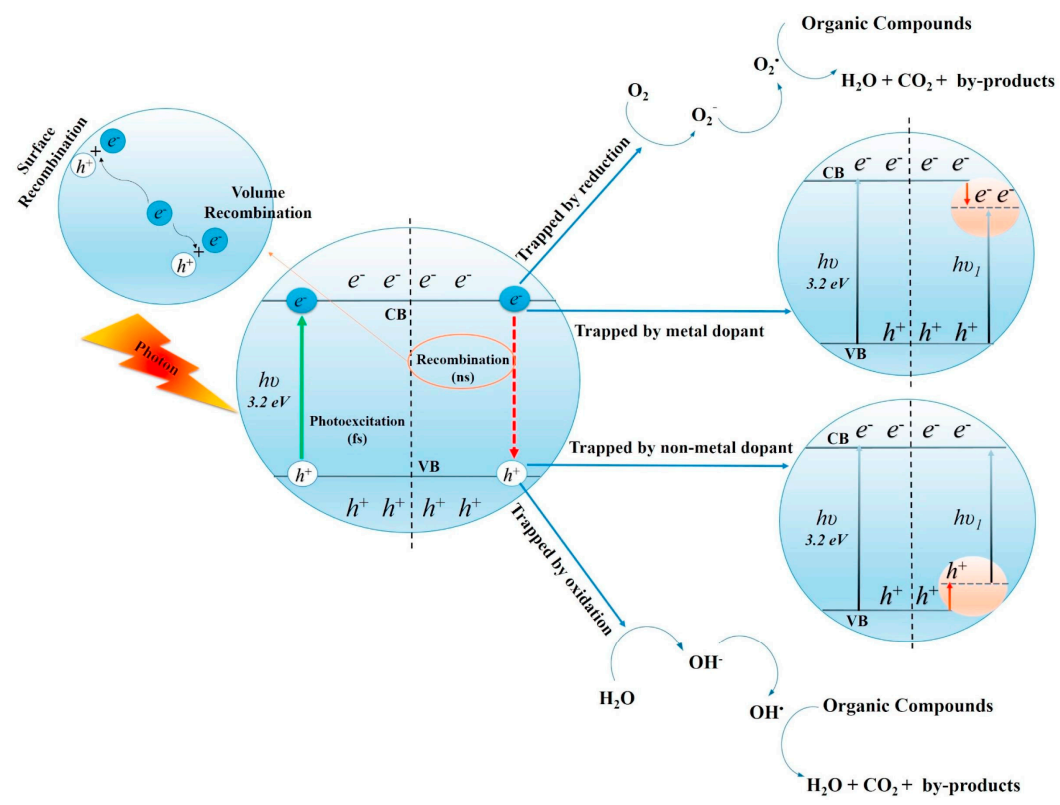

Figure 1. Mechanisms of photocatalytic oxidation for the removal of VOCs [14]. (reproduced from [14], with permission from Elsevier, 2019).

Most of the VOCs in indoor air are aromatics, aldehydes, and halocarbons, and they are rich in the established, new and renovated buildings [15]. Measurements indicate that similar exposure level is shared by VOCs in various indoor and building materials, and coverings are the major sources of VOCs [16]. VOCs are common in industry [5] and widely used in construction projects. Since many VOCs will off-gas a significant proportion of their volume in a relatively short time, the VOC concentrations could be much higher than typical ambient levels in newly-constructed or decorated buildings [2]. To reduce the VOC emissions and indoor concentrations inside the buildings, some proposed to bake-out the housing unit with a radiant floor-heating system [17], and a long-enough bake-out could deplete solvents and reduce VOC emissions [18]. While a more efficient method is to adopt photocatalysis such as $\mathrm{TiO}_{2}$, these materials can be applied on buildings as a coating or paint, or synthesised with mortar, which will further affect the aesthetics, sanitation and efficiency of the buildings [19-21]. Therefore, special attention should be paid to the construction materials. 
Since the topic has been investigated for decades, many researchers have summarized the materials for the removal [5,22] and sensing [23,24] of VOCs. Most references have been reviewed based on a specific category of material, such as $\mathrm{TiO}_{2}[13,25,26]$, graphene-based materials [27], zinc indium sulphide [28] and silica-nanosphere-based materials [29] etc., or focusing on the catalytic oxidation processes in a specific situation such as low temperature [30], visible light [31,32], or based on a summary from the perspective of various VOCs [5]. However, few have been done from a material perspective together with the consideration of applications on buildings. In this review paper, we do not discuss adsorption-based materials because there are already existing review papers [5,9]. Since the performances of the catalytic oxidations are different for various materials, it is reasonable to categorize by their physiochemical characteristics, which will further affect their applications on buildings. Therefore, this review proposed a novel summary on the materials for catalytic removal of VOCs and their applications on buildings (Figure 2). Morphology, synthesis, performance, and their applications will be explained in detail. This review will further contribute to the applications of photocatalysis materials on buildings.

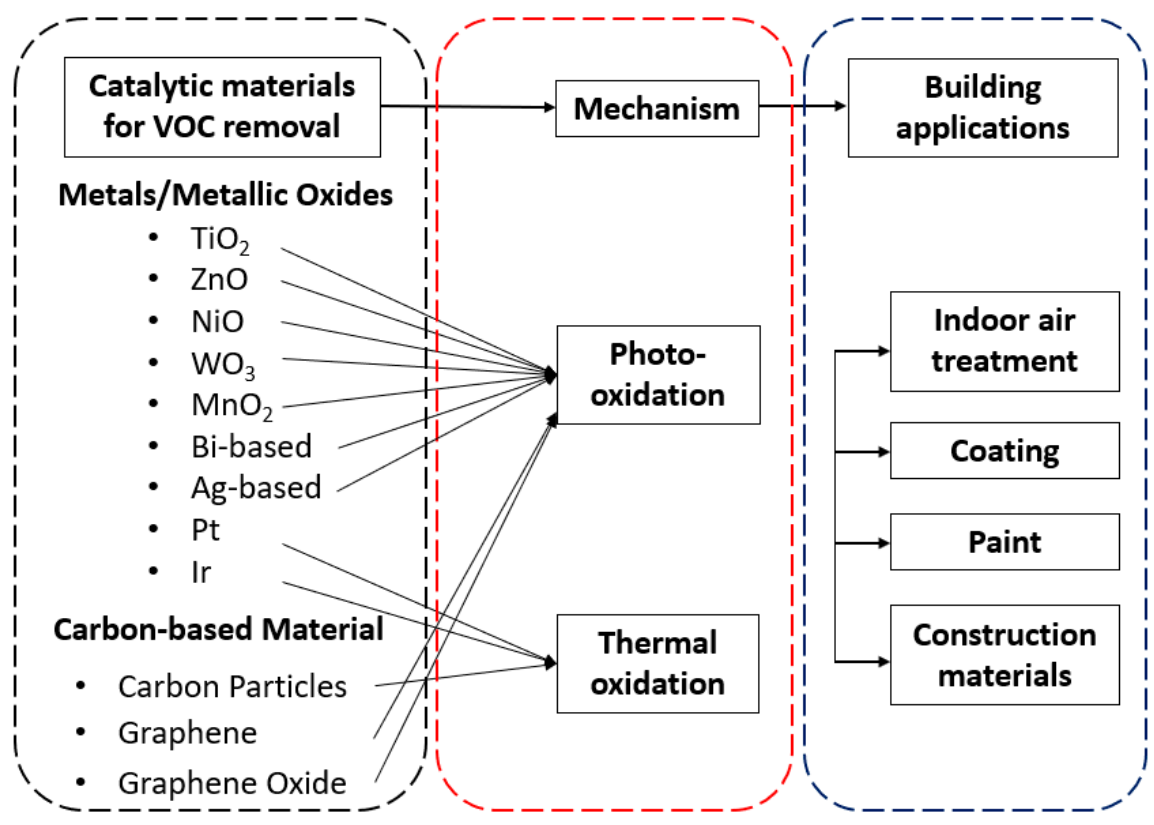

Figure 2. Outline of this review paper.

\section{Materials}

This review will summarize the materials used for catalytic oxidation of VOCs. The commonly used materials and their characteristics have been listed in Table 1. For this study, catalysts used for the oxidation of VOCs can be classified into two major groups: metallic oxide catalysts and carbon-cased materials. 
Table 1. Commonly used materials for catalytic removal of VOCs.

\begin{tabular}{|c|c|c|c|c|c|c|c|c|c|}
\hline No. & Catalytic & Category & VOC & Nanomaterial & Morphology & Medium & Doping Concentration & Synthesis & Ref \\
\hline 1 & Photo- & $\mathrm{TiO}_{2}$ & Trichloro-ethylene & $\begin{array}{c}\text { nanostructured } \mathrm{TiO}_{2} \\
\text { particles }\end{array}$ & $\begin{array}{c}\text { Primary particle size: } 2.3-30 \mathrm{~nm}, \\
\text { secondary particle size: } \\
100-900 \mathrm{~nm}\end{array}$ & titanium isopropoxide & $\begin{array}{l}\text { water concentrations: } 2.3,0.3 \text {, } \\
0.27 \text {, and } 0.18 \mathrm{M}\end{array}$ & $\begin{array}{l}\text { low-temperature synthesis, } \\
\text { modified sol-gel method }\end{array}$ & [33] \\
\hline 2 & Photo- & $\mathrm{TiO}_{2}$ & Toluene & Titanium isopropoxide & Primary particle size:11 nm & isopropanol-water solution & $\begin{array}{l}2.5 \mathrm{~mL} \mathrm{H}_{2} \mathrm{O}, 25 \mathrm{~mL} \text { ethanol, } \\
150 \text {-mL (hydrothermal) }\end{array}$ & $\begin{array}{l}\text { sol-gel synthesis, thermal \& } \\
\text { hydrothermal methods }\end{array}$ & {$[34]$} \\
\hline 3 & Photo- & $\mathrm{TiO}_{2}$ & Toluene & $\mathrm{TiO}_{2}$ thin films & $\begin{array}{l}\text { particle sizes less than } 100 \mathrm{~nm} \text {, } \\
\text { monocrystalline nanodiamond }\end{array}$ & $\begin{array}{c}\text { Titanium (IV) } \\
\text { tetraisopropoxide (TTIP) } \\
\left(\mathrm{Ti}\left(\mathrm{OCH}\left(\mathrm{CH}_{3}\right)_{2}\right)_{4}\right) \text { and water } \\
\end{array}$ & & $\begin{array}{l}\text { detonation method } \\
\text { (purchased from } \\
\text { microdiamant) }\end{array}$ & [35] \\
\hline 4 & Photo- & $\mathrm{TiO}_{2}$ & $\begin{array}{l}\text { Toluene, } \\
\text { acetaldehyde }\end{array}$ & $\begin{array}{l}\mathrm{TiO}_{2} \text { nanotubes (TNT) \& } \\
\text { nanopartcles (TNP) film; } \\
\text { commercial } \mathrm{TiO}_{2}(\mathrm{P} 25)\end{array}$ & $\begin{array}{c}\text { average surface area of } 50 \mathrm{~m}^{2} \\
\mathrm{~g}^{-1}, \text { primary particle size: } 20-30 \\
\text { nm, channel pores diameter: } \\
40-60 \mathrm{~nm} \text {, tube length: } \\
9.5( \pm 0.9) \mu \mathrm{m} .\end{array}$ & $\begin{array}{c}\text { [TNP] Ethanol } \\
\text { [TNT] ethylene glycol } \\
\text { electrolyte }\end{array}$ & $\begin{array}{c}\text { [TNP] } 0.15 \mathrm{~g} / \mathrm{mL} \\
\text { [TNT] 1st anodization: } 0.5 \mathrm{wt} \% \\
\mathrm{NH}_{4} \mathrm{~F} \text { and } 3 \mathrm{wt} \% \mathrm{H}_{2} \mathrm{O} ; 2 \text { 2nd: } 0.3 \\
\text { wt } \% \mathrm{NH}_{4} \mathrm{~F} \text { and } 1 \mathrm{wt} \% \mathrm{H}_{2} \mathrm{O} .\end{array}$ & $\begin{array}{l}\text { [TNP] doctor-blade method } \\
\text { [TNT]two-step } \\
\text { electrochemical anodization }\end{array}$ & [36] \\
\hline 5 & Photo- & $\mathrm{TiO}_{2}$ & Toluene & $\begin{array}{l}\text { Ti-foil }(99.7 \%, 0.25 \mathrm{~mm}, \\
\text { Aldrich, USA) }\end{array}$ & $\begin{array}{l}\text { top and bottom opened structure } \\
\text { of which thediameters are } 100 \\
\mathrm{~nm} \text { and } 50 \mathrm{~nm} \text {, respectively } \\
\text { NP@DNT films of } 15( \pm 2) \mu \mathrm{m}\end{array}$ & $\begin{array}{l}\text { ethylene glycol solution } \\
\text { containing } 0.25 \mathrm{wt} \% \mathrm{NH} 4 \mathrm{~F} \\
\text { and } 0.3 \text { vol } \% \text { distilled water }\end{array}$ & & $\begin{array}{l}\text { potentiostatic anodization } \\
\text { method }\end{array}$ & [37] \\
\hline 6 & Photo- & $\mathrm{TiO}_{2}$ & Hexane, methanol & $\begin{array}{c}\text { anatase and rutile } \mathrm{TiO}_{2} \\
\quad(0.1 \mathrm{~mol})\end{array}$ & $\begin{array}{l}\text { Surface area between } 39 \text { to } \\
84 \mathrm{~m}^{2} / \mathrm{g} \text { (given in table) }\end{array}$ & $\begin{array}{l}1.5 \text { mol anhydrous Ethanol, } \\
\text { water-ethanol solution } \\
\text { containing } 1 \text { mol ethanol } \\
\text { with a ratio of } \\
\text { water:butoxide = 50:1. }\end{array}$ & $\begin{array}{l}\text { aqueous } \mathrm{HNO}_{3} \text { solution of } \\
\text { various concentration }(0.1-1.0 \\
\text { mol/L) with the ratio of solid }(\mathrm{g}) \text { : } \\
\text { liquid }(\mathrm{mL})=1: 10\end{array}$ & hydrothermal method & [38] \\
\hline 7 & Photo- & $\mathrm{TiO}_{2}$ & Toluene & $\begin{array}{c}\text { Anatase/brookite/rutile } \\
\text { tricrystalline } \mathrm{TiO}_{2}\end{array}$ & amorphous $\mathrm{TiO}_{2}$ suspension & $\mathrm{HNO}_{3}$ solution $(65 \%)$ & $\begin{array}{c}\text { The molar ratios of } \mathrm{HNO}_{3} \text { to } \\
\text { TBOT (RHNO3) were varied } \\
\text { from } 0.2 \text { to } 1.2 \text { at intervals of } 0.2 \\
\text { by varying the volume of } \\
\mathrm{HNO}_{3} \text { solution. }\end{array}$ & $\begin{array}{c}\text { low-temperature } \\
\text { hydrothermal method }\end{array}$ & [39] \\
\hline 8 & Photo- & $\mathrm{TiO}_{2}$ & Toluene & co-alloying $\mathrm{TiO}_{2}$ & $\begin{array}{l}\text { fine bright yellow powder, } \\
\text { primary particles diameter: } \\
\qquad 1-2 \mu \mathrm{m}\end{array}$ & $\begin{array}{l}\mathrm{TiCl}_{4} \text { reacted with } \mathrm{NbCl} 15 \text { and } \\
\text { urea in an ethanol solution }\end{array}$ & $\begin{array}{l}\text { toluene concentrations: } 1 \sim 5 \mathrm{ppm} \text {; } \\
\text { relative humidity: } 25 \sim 65 \% \text {; air } \\
\text { velocity: } 0.78 \sim 784 \mathrm{~cm} / \mathrm{s} ; \\
\text { irradiancy: } 42 \sim 95 \mathrm{~W} / \mathrm{m}^{2}\end{array}$ & urea-glass synthesis & [40] \\
\hline 9 & Photo- & $\mathrm{TiO}_{2}$ & Isopropyl alcohol & $\begin{array}{c}\text { Hybrid } \mathrm{Cu}_{x} \mathrm{O} / \mathrm{TiO}_{2} \\
\text { Nanocomposites }\end{array}$ & $\begin{array}{c}\text { Commercial } \mathrm{TiO}_{2} \text { (rutile phase, } \\
15 \mathrm{~nm} \text { grain size, } 90 \mathrm{~m}^{2} / \mathrm{g} \text { specific } \\
\text { surface area) }\end{array}$ & $\begin{array}{l}\mathrm{CuCl}_{2} \text { solution, } \mathrm{NaOH} \text { and } \\
\text { glucose solutions (reduce \& } \\
\text { control the } \mathrm{Cu}^{\mathrm{I}} / \mathrm{Cu}^{\mathrm{II}} \text { ratio }\end{array}$ & $\begin{array}{c}10 \mathrm{~mL} \text { of } \mathrm{CuCl}_{2} \text { solution. } \\
\text { Weight fraction of } \mathrm{Cu}_{\mathrm{TiO}} \text { is } \\
1 \times 10^{3}: 2 \times 10^{2} \text {. }\end{array}$ & simple impregnation method & [41] \\
\hline 10 & Photo- & $\mathrm{TiO}_{2}$ & Toluene & commercial $\mathrm{TiO}_{2}$ (P25) & $\begin{array}{l}\text { Platinum nanoparticles in the } \\
\text { size of } 1-3 \mathrm{~nm} \text { were clearly } \\
\text { deposited on the surface of } \mathrm{TiO}_{2}\end{array}$ & $\begin{array}{l}0.5 \mathrm{wt} \% \text { Pt and } 30 \mathrm{mM} \\
\text { fluoride for VOC } \\
\text { degradation }\end{array}$ & $\begin{array}{l}\text { sodium fluoride }(10,30 \text {, and } \\
50 \mathrm{mM}) \text { and } \mathrm{Pt}(0.1,0.5, \text { and } \\
1 \mathrm{wt} \%)\end{array}$ & photo deposition method & [42] \\
\hline
\end{tabular}


Table 1. Cont.

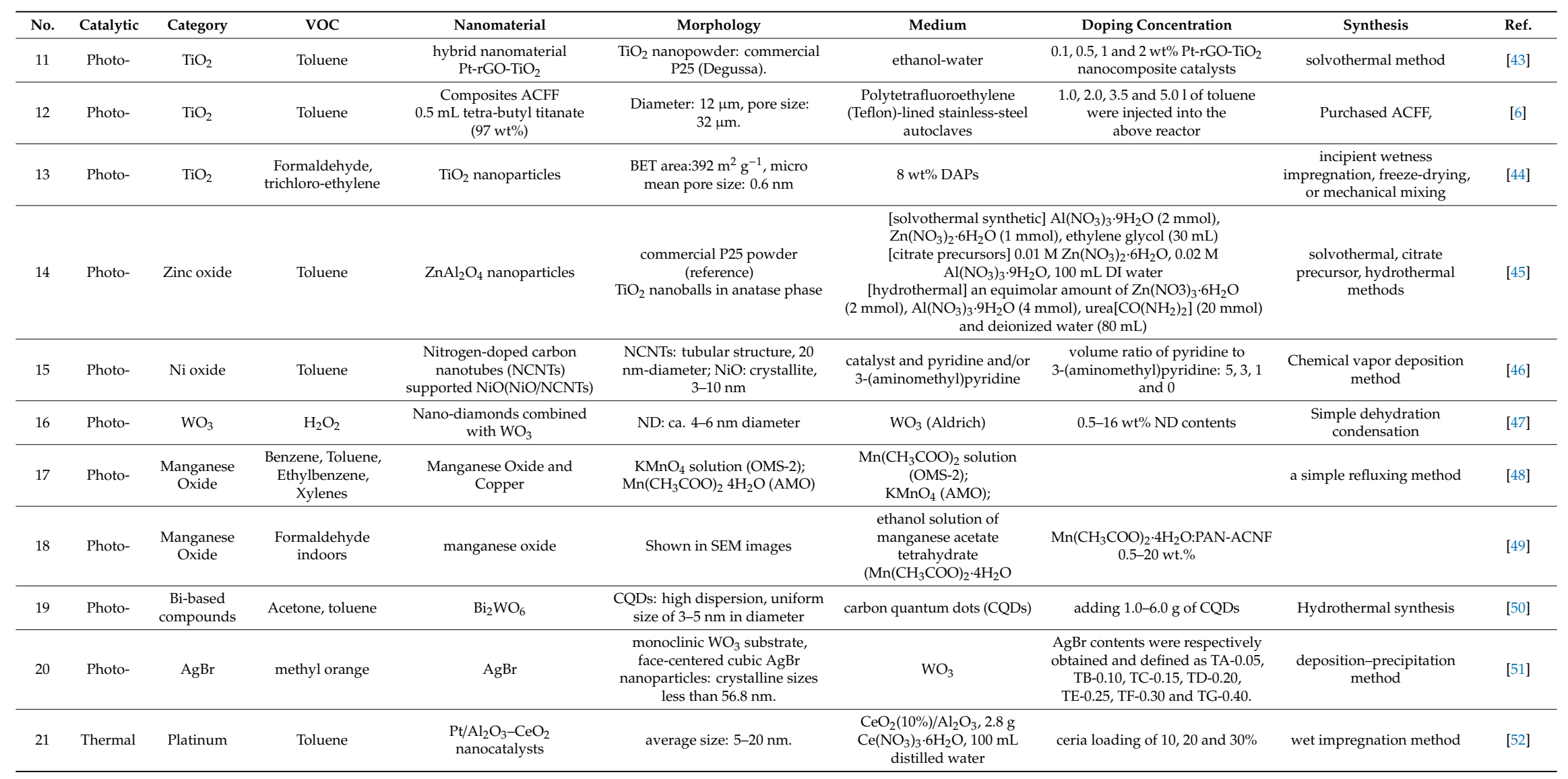


Table 1. Cont

\begin{tabular}{|c|c|c|c|c|c|c|c|c|c|}
\hline No. & Catalytic & Category & VOC & Nanomaterial & Morphology & Medium & Doping Concentration & Synthesis & Ref \\
\hline 22 & Thermal & Platinum & benzene & $\mathrm{Pt} / \mathrm{Al}_{2} \mathrm{O}_{3}$ & $\begin{array}{l}\text { Pt particle sizes between } 1.2-2.2 \\
\mathrm{~nm}\end{array}$ & $\mathrm{H}_{2} \mathrm{PtCl}_{6} \cdot 6 \mathrm{H}_{2} \mathrm{O}$ & $\begin{array}{c}\mathrm{Pt} / \mathrm{Al}_{2} \mathrm{O}_{3-\mathrm{x}}, \mathrm{x}: \mathrm{pH} \text { value of } 7.0, \\
9.0 \text { and } 11.0\end{array}$ & $\begin{array}{l}\text { modified ethylene glycol } \\
\text { (EG) reduction approach }\end{array}$ & [53] \\
\hline 23 & Thermal & Platinum & $\begin{array}{l}\text { Formaldehyde } \\
\text { (HCHO) }\end{array}$ & $\mathrm{Pt} / \mathrm{TiO}_{2} / \mathrm{Al}_{2} \mathrm{O}_{3}$ & BET area from 16.5 to $182.5 \mathrm{~m}^{2} / \mathrm{g}$ & $\left(\mathrm{NH}_{4}\right)\left[\mathrm{TiO}\left(\mathrm{C}_{2} \mathrm{O}_{4}\right)_{2}\right]$ & $\begin{array}{c}\text { The platinum loading: } 0.62, \\
1.26,1.19 \text { and } 1.25 \mathrm{gm}^{-2}\end{array}$ & $\begin{array}{l}\text { Electro-deposition } \\
\text { technology }\end{array}$ & {$[54]$} \\
\hline 24 & Thermal & Silica-iridium & Toluene & $\begin{array}{l}\text { chloride-ion free iridium } \\
\text { acetylacetonate, } \operatorname{Ir}(\mathrm{AcAc})_{3}\end{array}$ & $\sim 5$ to $27 \mathrm{~nm}$ & $\mathrm{SiO}_{2}$ Degussa Aerosil 200 & $\begin{array}{l}\text { Size of iridium particles: } \sim 5 \text { to } \\
27 \mathrm{~nm} \text { (calcination temperature } \\
350 \sim 750^{\circ} \mathrm{C} \text { ) }\end{array}$ & $\begin{array}{l}\text { incipient wetness } \\
\text { impregnation }\end{array}$ & [55] \\
\hline 25 & Thermal & Carbon & $\begin{array}{l}\text { benzene, toluene, } \\
\text { ethylbenzene, and } \\
\text { oxylene }\end{array}$ & $\begin{array}{l}\text { Pt/carbon nanotube (CNT) } \\
\text { Multiwalled carbon } \\
\text { nanotubes (MWCNT) }\end{array}$ & $\begin{array}{c}\text { CNTs: } 20-50 \mathrm{~nm} \text { column } \\
\text { diameters MWCNTs: } 20-50 \mathrm{~nm} \\
\text { diameters }\end{array}$ & $\begin{array}{l}\text { acid treatment using } \mathrm{HF} \text {, } \\
\mathrm{H}_{2} \mathrm{SO}_{4} \text {, and } \mathrm{HNO}_{3}\end{array}$ & $\begin{array}{l}\text { Pt content in the catalysts } \\
\text { ranging from } 10 \text { to } 30 \mathrm{wt} \% \text {. }\end{array}$ & $\begin{array}{l}\text { a molecular-level mixing } \\
\text { method }\end{array}$ & [56] \\
\hline 26 & Photo- & $\begin{array}{l}\text { Carbon } \\
\text { based }\end{array}$ & $\begin{array}{l}\text { Volatile Aromatic } \\
\text { Pollutant }\end{array}$ & $\mathrm{TiO}_{2 \_ \text {graphene }}$ & Shown in SEM image & An ethanol-water solvent & $\begin{array}{c}\text { P25_GR with weight addition } \\
\text { ratios of } 0.2,0.5,1,2,5,10 \text {, and } \\
30 \% \text { GR. }\end{array}$ & facile hydrothermal reaction & [57] \\
\hline 27 & Photo- & Carbon-based & methanol & $\begin{array}{l}\text { graphene oxide, reduced } \\
\text { graphene oxide, and } \\
\text { few-layer graphene }\end{array}$ & $\begin{array}{c}\text { BET area }\left(\mathrm{m}^{2} / \mathrm{g}\right): \\
\mathrm{rGO}+\mathrm{TiO}_{2}: 49.34, \mathrm{GO}+\mathrm{TiO}_{2}: \\
43.79, \mathrm{G}^{2}+\mathrm{TiO}_{2}: 41.54\end{array}$ & Polyacrylonitrile & $\begin{array}{l}\text { a polymer concentration of } 5 \% \\
(w / w) \text { in } \\
N, N \text {-dimethylformamide. }\end{array}$ & $\begin{array}{c}\text { hydrothermal method } \\
\text { (reduced graphene oxide); } \\
\text { others purchased }\end{array}$ & [58] \\
\hline
\end{tabular}




\subsection{Metallic Oxides}

\subsubsection{Titanium Dioxide $\left(\mathrm{TiO}_{2}\right)$}

With a wide band-gap energy, durability against photo-corrosion, low toxicity, and low cost, $\mathrm{TiO}_{2}$ is regarded as the most efficient and applicable material [59]. In 1972, the photoelectrochemical decomposition of water under irradiation with light on $\mathrm{TiO}_{2}$ was found for the first time [60]. Photocatalysis performances of $\mathrm{TiO}_{2}$ and its derivatives were studied over decades.

The photocatalyst performance can be affected by the structure and morphology [33] and treatments [34] of the $\mathrm{TiO}_{2}$ particles. Maira et al. [33] investigated the effects of different synthesis parameters on the size and morphology of the $\mathrm{TiO}_{2}$ particles, and the trichloroethylene degradation over $\mathrm{TiO}_{2}$ catalyst exhibits a maximum at a primary particle size of $7 \mathrm{~nm}$. They [34] further compared the treatments applied to an amorphous $\mathrm{TiO}_{2}$ precursor for obtaining nanosized $\mathrm{TiO}_{2}$ particles. Compared to the anatase $\mathrm{TiO}_{2}$ treated with the thermal method, the one with the hydrothermal method can improve the photo activity and showed a higher number of hydrogen-bonded hydroxyl groups that are more stable under RT outgassing and a stronger adsorption ability on Benzaldehyde.

$\mathrm{TiO}_{2}$ with different morphologies showed different photocatalytic performances. Lee et al. [35] developed novel nanostructured gas filtering systems with $\mathrm{TiO}_{2}$ thin films using atomic layer deposition (ALD) for VOCs, which showed a superior efficiency for the toluene adsorption. Weon and Choi [36] compared the photocatalytic activities of $\mathrm{TiO}_{2}$ nanotubes (TNT) and $\mathrm{TiO}_{2}$ nanoparticles (TNP) film during the repeated cycles of photocatalytic degradation of gaseous toluene and acetaldehyde. Figure $3 \mathrm{a}$,b shows the TEM images of fresh TNP and TNT, respectively. The photocatalytic activity of TNT showed only moderate reduction after the five cycles of toluene degradation, whereas TNP underwent rapid deactivation as the photocatalysis cycles were repeated, even in a more oxidizing atmosphere (Figure $3 c, d$ ). With a highly-ordered open channel structure, TNT can easily supply $\mathrm{O}_{2}$ molecules to the active sites with less mass transfer limitation, which prevents the TNT surface from carbonaceous residues accumulation. It indicated that the structural characteristics of TNT are highly advantageous in preventing the catalyst deactivation during the photocatalytic degradation of aromatic compounds. Weon et al. [37] later synthesized freestanding doubly open-ended $\mathrm{TiO}_{2}$ nanotubes (DNT) film, which exhibited higher activity and durability for the photocatalytic degradation of gaseous acetaldehyde and toluene than $\mathrm{TiO}_{2}$ nanotubes. If the freestanding DNT film was additionally loaded with $\mathrm{TiO}_{2}$ nanoparticles (NP@DNT) in the inner wall, the activity for VOC degradation will be increased by 1.3 and 1.8 times of those for bare DNT and bare TNT, respectively. However, the loading of $\mathrm{TiO}_{2}$ nanoparticles on $\mathrm{TiO}_{2}$ nanotubes showed a lower activity than bare TNT.

$\mathrm{TiO}_{2}$ primarily exists in three crystal phases: anatase, brookite and rutile. Among them, the anatase form appears to be the most photoactive and the most practical for widespread environmental applications [25]; the brookite was once regarded to not be suitable as a photocatalyst $[25,61]$, and later the successful synthesis of nanostructured brookite was showed to greatly enhance the photocatalytic performance [62]. Wu et al. [38] investigated the synergetic effect between anatase and rutile nanoparticles in gas-phase photocatalytic oxidations of hexane and methanol. The synergetic effect could be more significant if anatase and rutile particles are closely contacted. The long-term experiment proves the stability of the photocatalyst activity, and it cannot be improved by sulfation, which works well for the single-phase anatase $\mathrm{TiO}_{2}$.

The tricrystalline $\mathrm{TiO}_{2}$ shows higher photocatalytic activity and durability toward gaseous toluene than bicrystalline $\mathrm{TiO}_{2}$ [39]. To remove toluene from the indoor air efficiently and economically, Chen et al. [39] synthesized anatase/brookite/rutile tricrystalline $\mathrm{TiO}_{2}$ by a low-temperature hydrothermal route with $\mathrm{HNO}_{3}$. As shown in Figure 4a, the one with $\mathrm{RHNO}_{3}=0.8(80.7 \%$ anatase, $15.6 \%$ brookite and 3.7\% rutile) had the highest photocatalytic activity about 3.85-fold higher than that of $\mathrm{P} 25 \mathrm{TiO}_{2}$, which is a widely-used benchmark model photocatalyst coexisting anatase and rutile phases. Moreover, the high activity did not significantly degrade even after five reuse cycles (Figure $4 b$ ). 

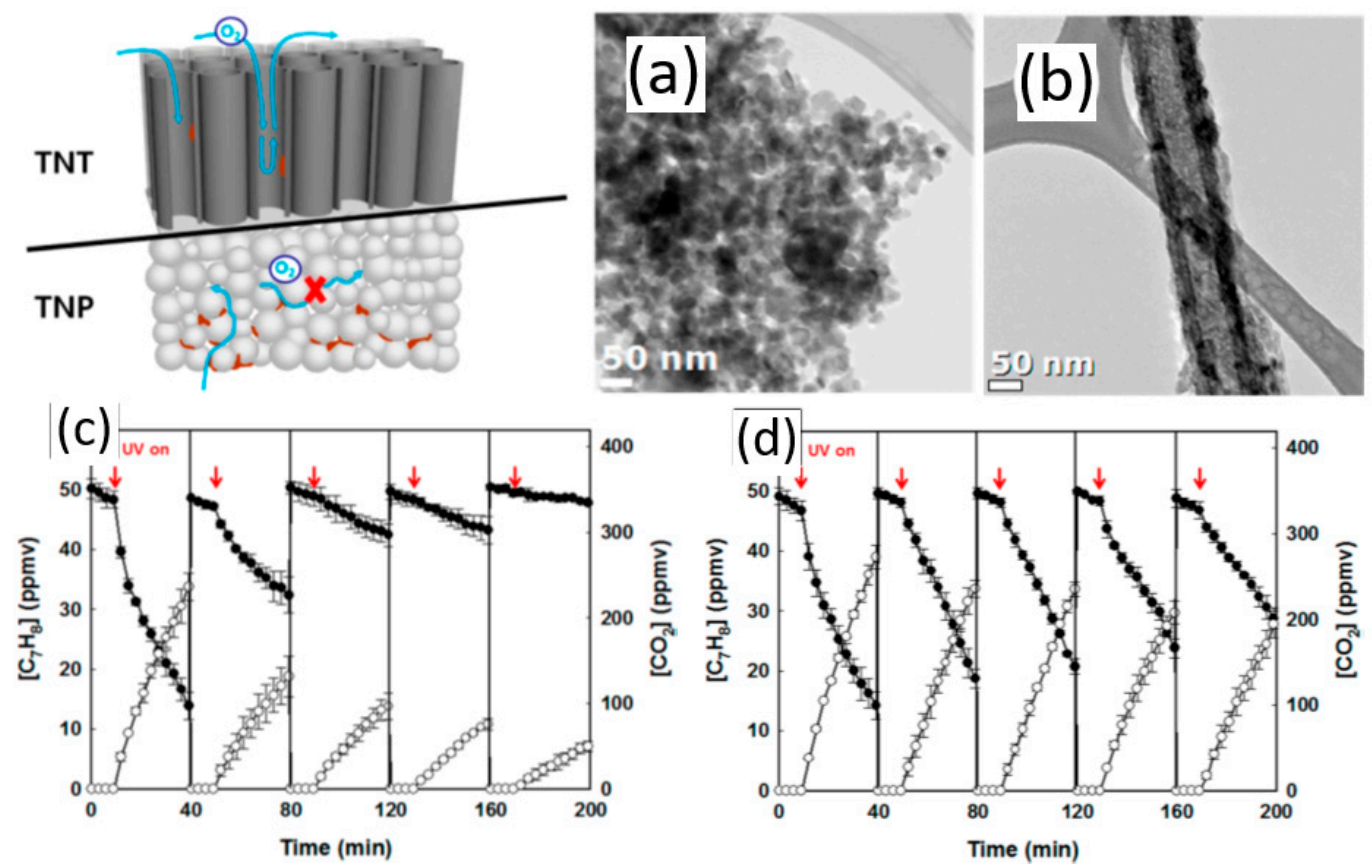

Figure 3. TEM images of fresh (a) TNP and (b) TNT; repeated photocatalytic degradation cycles of

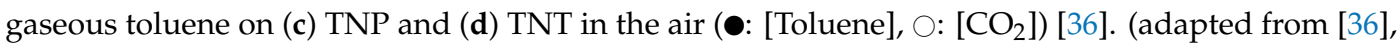
with permission from American Chemical Society, 2019).

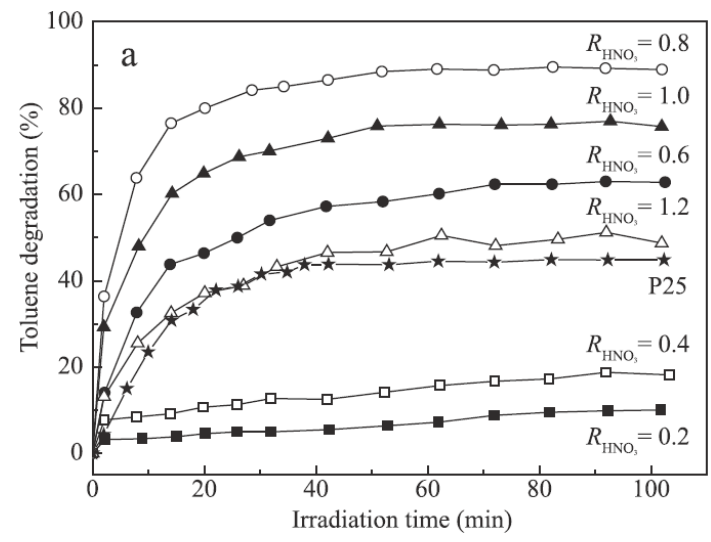

(a) Photodegradation of gaseous toluene

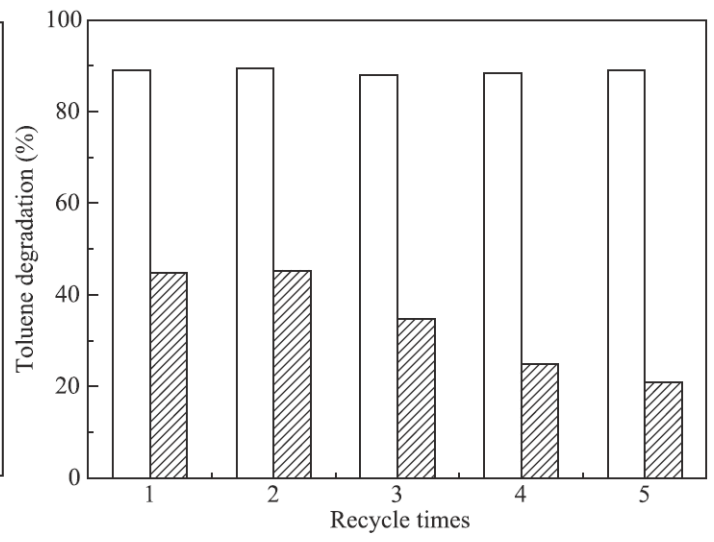

(b) Recycling test

Figure 4. Comparison results between $\mathrm{TiO}_{2}$ and $\mathrm{P} 25$ for (a) photodegradation rate of gaseous toluene and (b) recycling test over tricrystalline $\mathrm{TiO}_{2}-0.8$ (blank) and P25 (filled) for five repeat uses [39]. (adapted from [39], with permission from Elsevier, 2019).

However, the leading semiconductor photocatalyst, $\mathrm{TiO}_{2}$, also suffers from low photocatalytic activity under visible light activation because of its intrinsic wide band gap. Therefore, to increase the efficiency of $\mathrm{TiO}_{2}$ in the visible light region, $\mathrm{TiO}_{2}$ is modified with various nanomaterials including other metal oxides [40-42], carbonaceous nanomaterials [43] etc. Zhong et al. [40] developed a TiNbON compound (band energy of $2.3 \mathrm{eV}$ ) using urea-glass synthesis as a visible light responsive photocatalytic oxidation material for toluene degradation. Experimental results showed that the visible light-driven catalyst was able to remove up to $58 \%$ of the toluene and generated less formaldehyde than the commercial $\mathrm{TiO}_{2}$ with reasonable durability and stability. Qiu et al. [41] grafted nano- $\mathrm{Cu}_{\mathrm{x}} \mathrm{O}$ clusters onto $\mathrm{TiO}_{2}$ to generate an excellent risk-reduction material in indoor environments (Figure 5a). The Cu${ }^{\mathrm{II}}$ in the $\mathrm{Cu}_{\mathrm{x}} \mathrm{O}$ clusters enables $\mathrm{TiO}_{2}$ to protoxidize VOCs under visible light efficiently, and it has the antimicrobial properties under dark conditions due to $\mathrm{Cu}^{\mathrm{I}}$ species. Therefore, the efficient reduction of VOCs and antipathogenic activity could be achieved in hybrid $\mathrm{Cu}_{\mathrm{x}} \mathrm{O} / \mathrm{TiO}_{2}$ nanocomposites with a 
proper proportion of $\mathrm{Cu}^{\mathrm{I}}$ and $\mathrm{Cu}{ }^{\mathrm{II}}$ in $\mathrm{Cu}_{x} \mathrm{O}$. As shown in Figure $5 b$, the $\mathrm{Cu}_{\mathrm{x}} \mathrm{O} / \mathrm{TiO}_{2}$ sample shows a superior photocatalytic activity over the $\mathrm{TiO}_{2-x} \mathrm{~N}_{\mathrm{x}}$ sample with high quantum efficiencies and stability under long-term light irradiation.
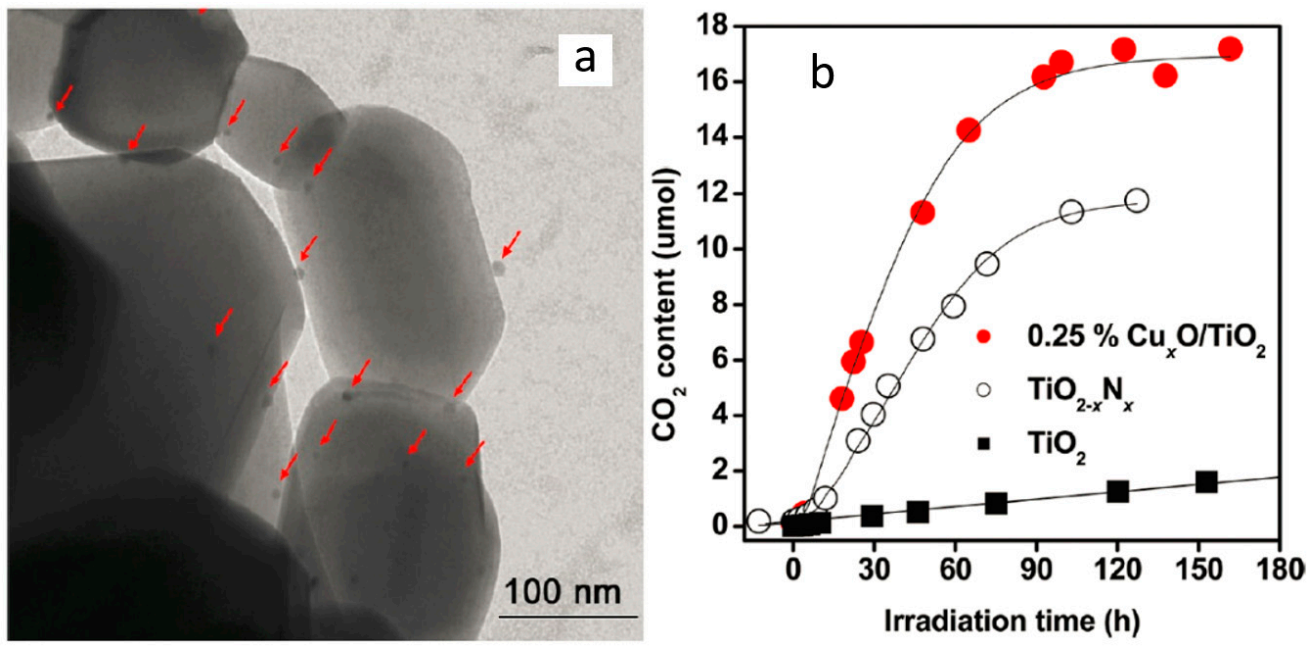

Figure 5. (a) TEM images of the $0.25 \% \mathrm{Cu}_{\mathrm{x}} \mathrm{O} / \mathrm{TiO}_{2}$ sample. $\mathrm{Cu}_{\mathrm{x}} \mathrm{O}$ clusters (marked by red arrows) were highly dispersed on the $\mathrm{TiO}_{2}$ surfaces; (b) comparative studies of $\mathrm{CO}_{2}$ generation over bare $\mathrm{TiO}_{2}, \mathrm{TiO}_{2-\mathrm{x}} \mathrm{N}_{\mathrm{x}}$, and $0.25 \% \mathrm{Cu}_{\mathrm{x}} \mathrm{O} / \mathrm{TiO}_{2}$ samples under the same conditions [41]. (adapted from [41], with permission from American Chemical Society, 2019).

Jo et al. [63] applied an annular reactor coated with unmodified or nitrogen (N)-doped $\mathrm{TiO}_{2}$ for VOCs removal in the indoor environment. The photocatalytic technique using $\mathrm{N}$-doped $\mathrm{TiO}_{2}$ was much superior to that for unmodified $\mathrm{TiO}_{2}$, and it can remove above $90 \%$ for four target compounds (ethyl benzene, $\mathrm{o}, \mathrm{m}$,p-xylenes) under conditions of less humidified environments, including a typical indoor comfort range (50-60\%). Weon et al. [42] modified $\mathrm{TiO}_{2}$ nanoparticles with $\mathrm{Pt}$ and fluoride and tested their durability for toluene removal. Figure 6a shows the HR-TEM of the composite. Although Pt/TiO 2 had a higher photocatalytic degradation activity than bare $\mathrm{TiO}_{2}$, it could be deactivated rapidly during repeated cycles. Among them, $\mathrm{F}_{-} \mathrm{TiO}_{2} / \mathrm{Pt}$ showed the highest photocatalytic activity and durability for toluene degradation (Figure 6b).

$\mathrm{Li}$ et al. [43] introduced a hybrid nanomaterial Pt-rGO-TiO 2 (Figure 7a). With a broad light wavelength absorption (800-2500 nm), the highly-active photo-thermal responsive catalyst can decompose VOCs efficiently under IR irradiation. As shown in Figure 7b, the light intensity can affect the efficiency of Pt-rGO-TiO 2 composites on the conversion of toluene and the yield of $\mathrm{CO}_{2}$. If the infrared irradiation intensity is $116 \mathrm{~mW} / \mathrm{cm}^{2}$, a maximum photo-thermal conversion efficiency of $14.1 \%$ would be achieved with a significant toluene conversion of $95 \%$ and a $\mathrm{CO}_{2}$ yield of $72 \%$, and a nearly 50 h stability duration.

Metal oxides also synthesized with adsorption materials to enhance their photocatalysis performances. Li et al. [6] firstly fabricated nanostructured $\mathrm{TiO}_{2} /$ activated carbon fiber-felt $(\mathrm{TiO} / \mathrm{ACFF})$ porous composites by the in-situ deposition of $\mathrm{TiO}_{2}$ microspheres on the carbon fibers in ACFF. Figure 8a shows hierarchical nanostructures constructed by nanocrystals of $\mathrm{TiO}_{2}$ microspheres. Due to the synergetic effects of nanostructured $\mathrm{TiO}_{2}$ and $\mathrm{ACFF}$, the $\mathrm{TiO}_{2} / \mathrm{ACFF}$ porous composites possess excellent adsorption and photodegradation properties for toluene. The ACFF in the $\mathrm{TiO}_{2} / \mathrm{ACFF}$ porous composites significantly enhances photocatalytic property for toluene by hindering the recombination of electron-hole pairs, reducing the $\mathrm{TiO}_{2}$ band gap energy to $2.95 \mathrm{eV}$ and accelerating toluene adsorption. 


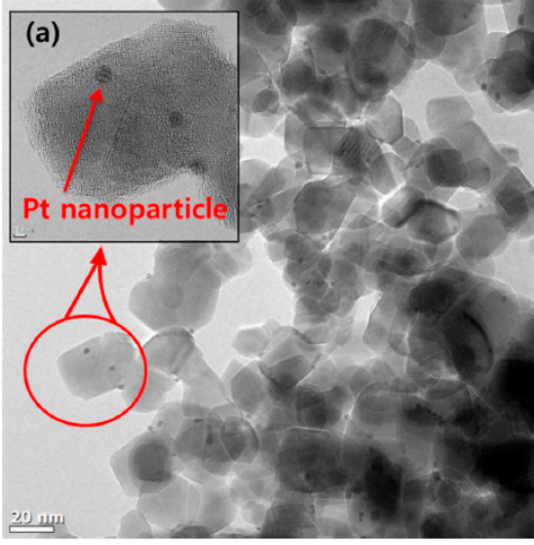

(a) HR-TEM image

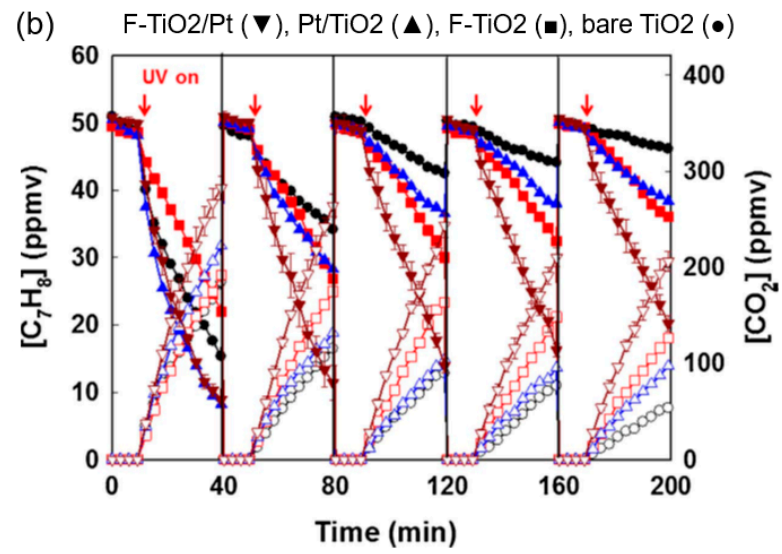

(b) Repeated photocatalytic degradation cycles.

Figure 6. (a) HR-TEM image and (b) repeated photocatalytic degradation cycles of gaseous toluene on $\mathrm{F}^{-\mathrm{TiO}_{2}} / \mathrm{Pt}$ [42]. (adapted from [42], with permission from Elsevier, 2019).
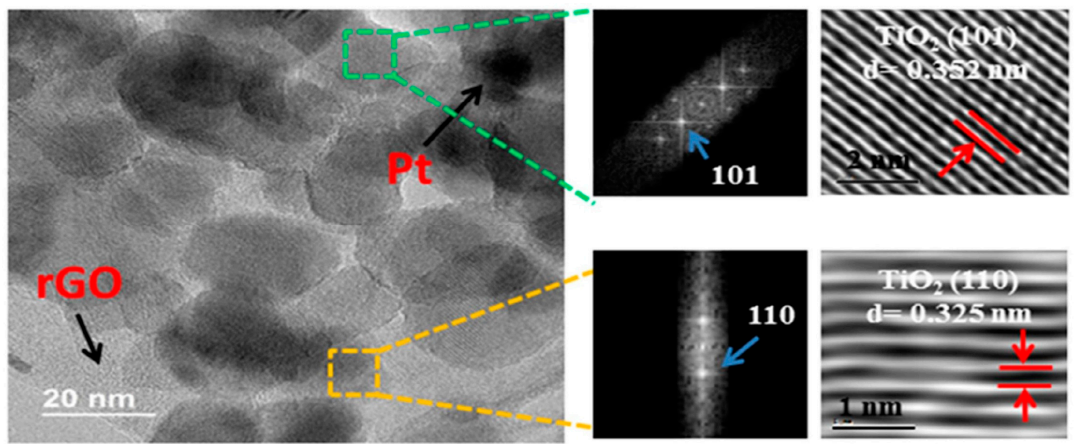

(a)

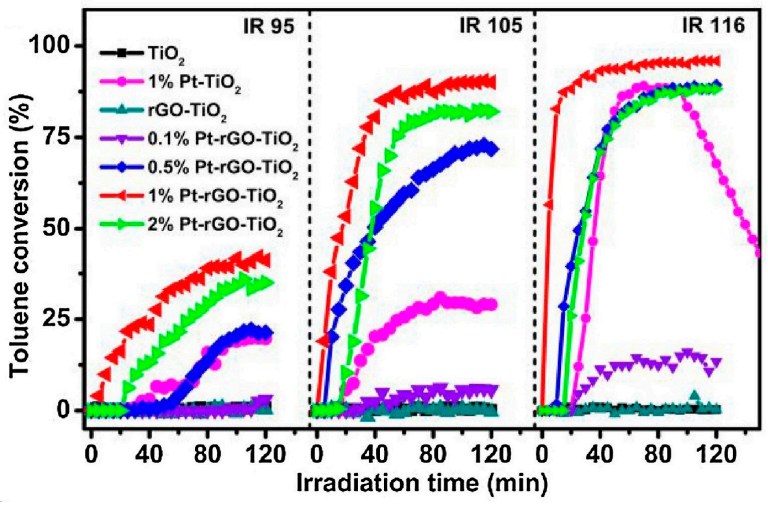

(b)

Figure 7. (a) High-angle annular dark-field scanning transmission electron microscopy images and HRTEM of $1 \% \mathrm{Pt}-\mathrm{rGO}-\mathrm{TiO}_{2}$; (b) time course of toluene conversion over $\mathrm{TiO}_{2}, 1 \% \mathrm{Pt}-\mathrm{TiO}_{2}$ and $\mathrm{x} \%$ Pt-rGO-TiO $2(x=0,0.1,0.5,1$ and 2$)$ under IR irradiation with various light intensities $(95,106$ and $116 \mathrm{~mW} / \mathrm{cm}^{2}$ ) [43]. (adapted from [43], with permission from Elsevier, 2019).

Similar combination can be found in Ref. [44], where the $\mathrm{TiO}_{2}$ nanoparticles (Ti-NP) were synthesized with decahedral anatase particles (DAPs), and their photocatalytic activity of $\mathrm{TiO}_{2} / \mathrm{zeolite}$ hybrids for VOCs oxidation was analyzed. $\mathrm{TiO}_{2}$ nanoparticles of $5 \mathrm{~nm}$, DAPs of ca. $100 \mathrm{~nm}$, and $1.0 \mu \mathrm{m}$ clusters of $\mathrm{TiO}_{2}$ made of $15 \mathrm{~nm}$ mean particle size characterized the three types of $\mathrm{TiO}_{2}$. The incorporation of $\mathrm{TiO}_{2}-\mathrm{NP}$ into the zeolitic material led to composites with around 10 times more photoactivity that the single titania particles. Elfalleh et al. [64] used $\mathrm{TiO}_{2}$-impregnated polyester and glass fiber to address the photocatalytic degradation aldehydes (air-solid interface). Also, the $\mathrm{TiO}_{2}$ nanoparticles were 
fixed by the glass fiber tissue coated with colloidal silica in reactors to photo-catalytically remove isovaleraldehyde [65] and isovaleric acid [66].

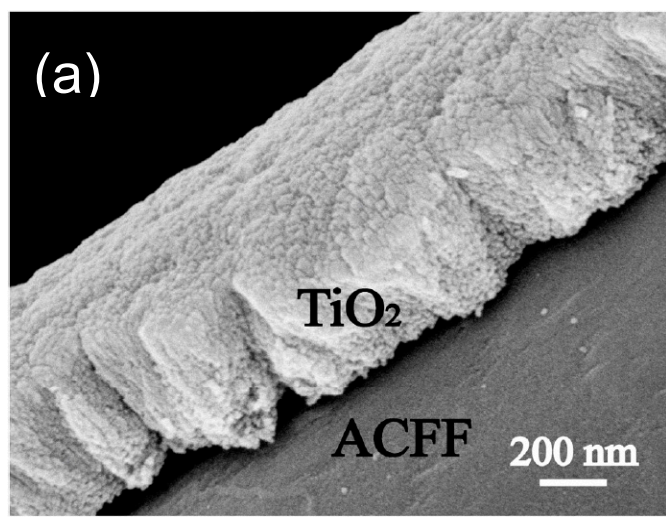

(a) SEM images

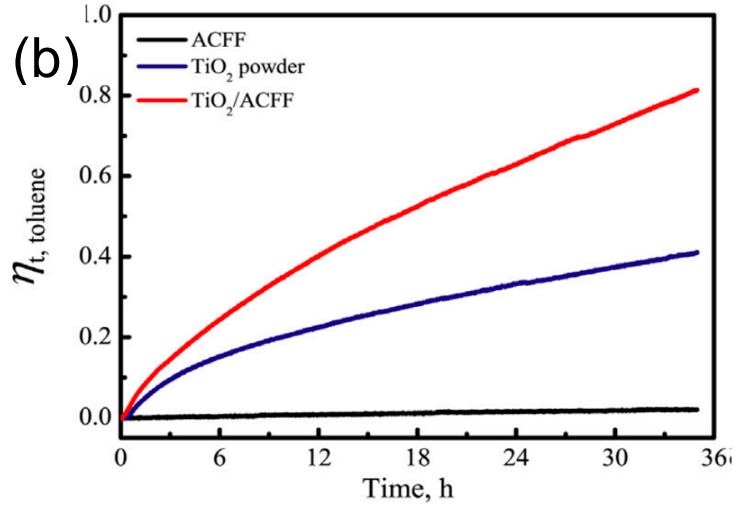

(b) Photocatalytic oxidation efficiencies of toluene

Figure 8. (a) SEM images and (b) Photocatalytic oxidation efficiencies of toluene as function of photocatalytic time under UV irradiation with $\mathrm{TiO}_{2}$ /ACFF porous composites [6]. (adapted from [6], with permission from Elsevier, 2019).

\subsubsection{Zinc Oxide}

As an alternative to $\mathrm{TiO}_{2}$, zinc oxide is considered to be a fast and efficient chemical decontamination of VOCs [67]. Li et al. [45] compared three synthetic methods to prepare $\mathrm{ZnAl}_{2} \mathrm{O}_{4}$ for the photocatalytic degradation of gaseous toluene: solvothermal, citrate precursor and hydrothermal methods, whose SEM figures can be found in Figure 9a-d. The photocatalytic performances of the $\mathrm{ZnAl}_{2} \mathrm{O}_{4}$ samples synthesized by facile solvothermal method exhibited about $90 \%$ photocatalytic efficiency of toluene (Figure 9e). The photocatalytic oxidation of gaseous pollutant over UV-illuminated $\mathrm{ZnAl}_{2} \mathrm{O}_{4}$ is a promising technique for air purification.

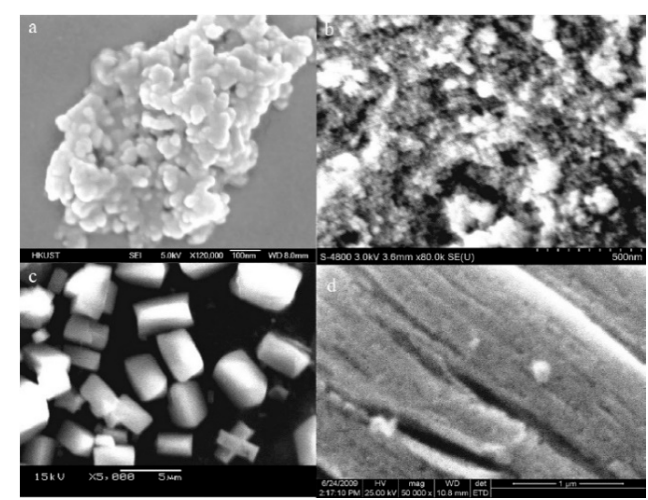

(a-d) SEM images for $\mathrm{ZnAl}_{2} \mathrm{O}_{4}$ nanoparticles.

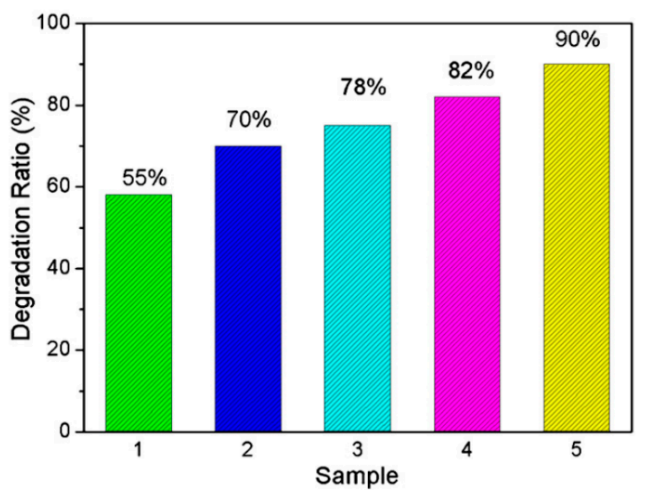

(e) Degradation percentage of toluene.

Figure 9. SEM images for $\mathrm{ZnAl}_{2} \mathrm{O}_{4}$ nanoparticles synthesized with (a) hydrothermal, (b) citrate precursors, (c,d) solvothermal synthetic methods. (e) The degradation percentage of toluene among 1 $\left(\mathrm{ZnAl}_{2} \mathrm{O}_{4}\right.$ nanoparticles + citrate precursors), $2\left(\mathrm{P}_{25} \mathrm{TiO}_{2}\right), 3\left(\mathrm{ZnAl}_{2} \mathrm{O}_{4}\right.$ nanoparticles + hydrothermal), $4\left(\mathrm{TiO}_{2}\right.$ nanoballs), and $5\left(\mathrm{ZnAl}_{2} \mathrm{O}_{4}\right.$ nanoparticles + solvothermal synthetic) samples under UV illumination [45]. (adapted from [45], with permission from Elsevier, 2019).

\subsubsection{Nickel Oxide}

Jiang et al. [46] compared the catalysis performance of nitrogen-doped carbon nanotubes (NCNTs) supported by $\mathrm{NiO}(\mathrm{NiO} / \mathrm{NCNTs})$ with different pyridine volume ratios (Figure 10a-d). The oxygen adspecies concentration and low-temperature reducibility of $\mathrm{NiO} / \mathrm{NCNT}$ increased with increasing 
the doped graphitic-like N(NG) content of NCNTs (Figure 10e). The optimized NiO/NCNTs-d catalyst with NG content of 6.22 at. \% can achieve a completed conversion of toluene at $248^{\circ} \mathrm{C}$, and has a TOF value of nearly 10 times $\mathrm{NiO} / \mathrm{CNTs}$ at $160{ }^{\circ} \mathrm{C}$.
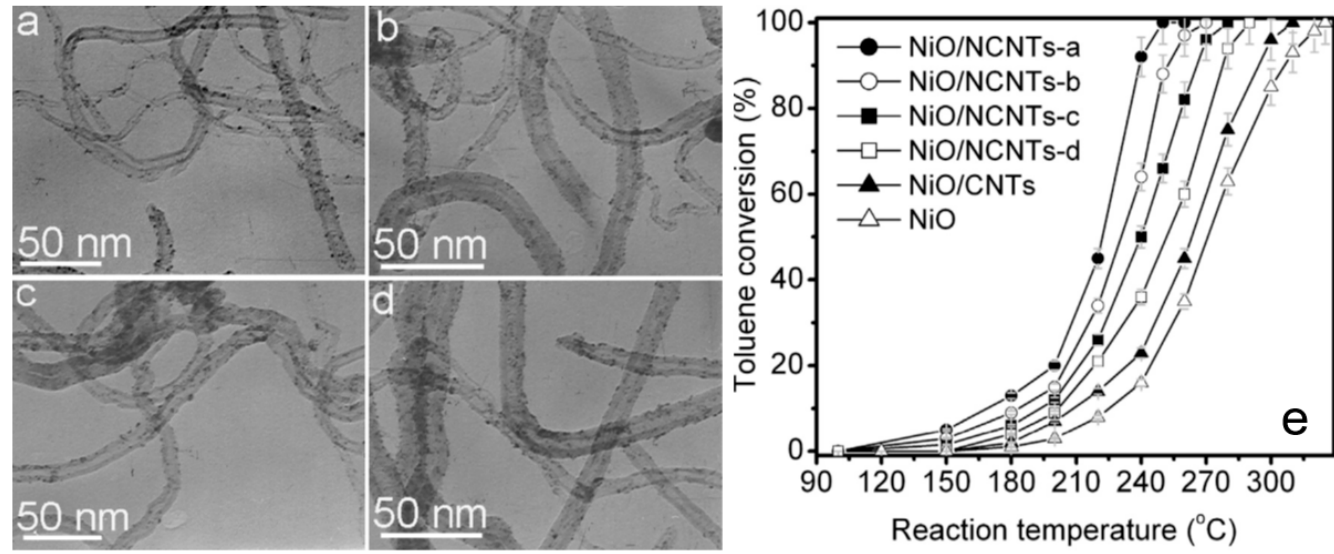

Figure 10. TEM images of $\mathrm{NiO} / \mathrm{NCNT}$ catalysts with the pyridine to 3-(aminomethyl) pyridine volume ratios of (a) 5, (b) 3, (c) 1 and (d) 0; and (e) their toluene conversion vs. reaction temperatures against those of NiO/CNTs [46]. (adapted from [46], with permission from Elsevier, 2019).

\subsubsection{Tungsten Triocide}

Kim et al. [47] combined nanodiamond (ND) with $\mathrm{WO}_{3}$ (as an alternative co-catalyst for Pt) to degrade VOCs under visible light. NDs-loaded WO3 showed a highly enhanced photocatalytic activity for the degradation of acetaldehyde ( $\sim 17$ times higher than bare $\left.\mathrm{WO}_{3}\right)$, which is more efficient than other well-known co-catalysts $\left(\mathrm{Ag}, \mathrm{Pd}, \mathrm{Au}\right.$, and $\mathrm{CuO}$ ) loaded onto $\mathrm{WO}_{3}$ and comparable to Pt-loaded $\mathrm{WO}_{3}$. the surface conductivity of $\mathrm{ND}$ loaded on $\mathrm{WO}_{3}$ plays a critical role in the overall photocatalysis. The photocatalytic activity of $\mathrm{NDs} / \mathrm{WO}_{3}$ was higher than that of $\mathrm{WO}_{3}$ loaded with other carbon-based co-catalysts (graphene oxide or reduced graphene oxide).

\subsubsection{Manganese Oxide}

Genuino et al. [48] synthesized cryptomelane-type octahedral molecular sieve (OMS-2) manganese oxide, amorphous manganese oxide (AMO), and mixed copper manganese oxide $\left(\mathrm{CuO} / \mathrm{Mn}_{2} \mathrm{O}_{3}\right)$ nanomaterials, together with commercial $\mathrm{MnO}_{2}$. Due to complex reasons including structure, morphology, hydrophobicity, and redox properties, OMS-2, $\mathrm{AMO}$, and $\mathrm{CuO} / \mathrm{Mn}_{2} \mathrm{O}_{3}$ showed higher oxidative activities than the commercial $\mathrm{MnO}_{2}$. Miyawaki et al. [49] developed a novel hybrid catalyst for long-lifetime formaldehyde removal, which deposits manganese oxide $\left(\mathrm{MnO}_{\mathrm{x}}\right)$ catalysts on a polyacrylonitril-based activated carbon nanofiber (PAN-ACNF) support. The combination of $\mathrm{MnO}_{\mathrm{x}}$ with PAN-ACNF induced synergic effects on the formaldehyde removal performance, which doubly improved the performance of PAN-ACNF in either dry or humid conditions without UV light. The manganese oxides were also interacted with cerium oxide [68] and CoAl mixed oxides [69] for a better catalytic removal of gaseous VOCs.

\subsubsection{Bi-Based Compounds}

Qian et al. [50] incorporated highly stable carbon quantum dots (CQDs) with $\mathrm{Bi}_{2} \mathrm{WO}_{6}$ to sufficiently photocatalytic removal of VOCs. The $\mathrm{CQDs} / \mathrm{Bi}_{2} \mathrm{WO}_{6}$ photocatalyst can extend the absorption into visible light region and improve the photoexcited charge separation in comparison with pristine $\mathrm{Bi}_{2} \mathrm{WO}_{6}$. This photocatalyst showed higher photocatalytic oxidation activities towards acetone and toluene under both UV-vis and visible light irradiation. 


\subsubsection{Ag-Based Compounds}

Kobayashi et al. [70] investigated the photocatalytic activity of $\operatorname{AgBr} . \operatorname{AgBr}\left(\mathrm{N}_{2}\right)$ prepared at $250{ }^{\circ} \mathrm{C}$ showed the highest $\mathrm{H}_{2}$ generation activity, although larger crystallites of Ag were observed. Cao et al. [51] synthesized a novel $\mathrm{AgBr} / \mathrm{WO}_{3}$ composite photocatalyst by loading $\mathrm{AgBr}$ on $\mathrm{WO}_{3}$ substrate via the deposition-precipitation method. $\mathrm{AgBr} / \mathrm{WO}_{3}$ displays good photocatalytic activity under visible light $(\lambda>420 \mathrm{~nm})$.

\subsubsection{Platinum Suported Material}

Abbasi et al. [52] prepared $\mathrm{Pt} / \mathrm{Al}_{2} \mathrm{O}_{3}-\mathrm{CeO}_{2}$ nanocatalysts with Pt loading of $1 \%$ and ceria loading of 10, 20 and $30 \%$ to be utilized in catalytic oxidation of BTX (Figure 11a). The results of toluene oxidation indicated that the synthesized nanocatalysts were highly active and able to remove nearly $100 \%$ of toluene and xylene and about $85 \%$ of benzene as representative VOCs (Figure 11b).

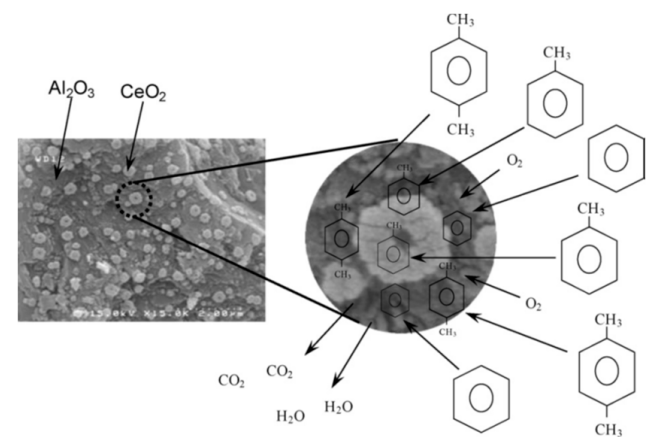

(a) Diagram

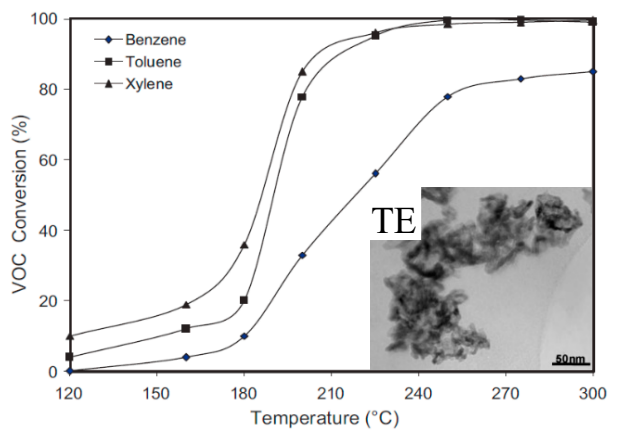

(b) Time-dependent profiles

Figure 11. (a) Reaction mechanism for total oxidation of VOCs over nanostructured $\mathrm{Pt} / \mathrm{Al}_{2} \mathrm{O}_{3}-\mathrm{CeO}_{2}$ catalysts. (b) Comparison of catalytic performance of synthesized $\mathrm{Pt}(1 \mathrm{wt} \%) / \mathrm{Al}_{2} \mathrm{O}_{3}-\mathrm{CeO}_{2}(30 \mathrm{wt} \%)$ nanocatalyst for total oxidation of benzene, toluene and xylene [52]. (adapted from [52], with permission from Elsevier, 2019).

Chen et al. [53] prepared a series of $\mathrm{Pt} / \mathrm{Al}_{2} \mathrm{O}_{3}$ catalysts by modified ethylene glycol (EG) reduction approach with $\mathrm{Pt}$ particle sizes between 1.2-2.2 nm. Pt/ $/ \mathrm{Al}_{2} \mathrm{O}_{3}$ catalyst with $1.2 \mathrm{~nm}$ Pt size exhibited optimum catalytic oxidation activity of benzene at $145^{\circ} \mathrm{C}$. The catalysts showed excellent adaptability for different VOCs and durability for benzene oxidation during the long-term continuous test, whether in dry air or in the coexistence of $\mathrm{CO}_{2}$, cyclohexane or $\mathrm{H}_{2} \mathrm{O}$. Wang et al. [54] prepared a $\mathrm{Pt} / \mathrm{TiO}_{2} / \mathrm{Al}_{2} \mathrm{O}_{3}$ catalyst on an anodic alumite plate for the catalytic decomposition of formaldehyde at ambient temperature. The developed catalyst has good activity on decomposing $\mathrm{HCHO}$ at ambient temperature. With quick activation of absorbing oxygen, the $\mathrm{Pt} / \mathrm{TiO}_{2} / \mathrm{Al}_{2} \mathrm{O}_{3}$ catalyst showed a high activity towards the catalytic decomposition of formaldehyde at ambient temperature.

\subsubsection{Iridium Particles}

Other oxides were also investigated, for example, Schick et al. [55] synthesized iridium particles supported on silica for the total oxidation of VOCs, and the catalytic activity increases when the iridium oxide particle size decreases.

\subsection{Carbon-Based Materials}

\subsubsection{Carbon-Based}

Joung et al. [56] fabricated a novel Pt/carbon nanotube (CNT) catalyst using a molecular-level mixing method (Figure 12a), and its performance on oxidation of benzene, toluene, ethylbenzene, and o-xylene (BTEX) was investigated at temperatures ranging from 40 to $150^{\circ} \mathrm{C}$ (Figure 12b). The oxidation activity was presumably promoted because of the higher surface BTEX concentration afforded by the 
adsorption capability of multiwalled carbon nanotubes. The catalyst was characterized by its unique hydrophobic property, which facilitates the conversion of BTEX with high activity at relatively low temperatures and was unaffected by moisture in the system.

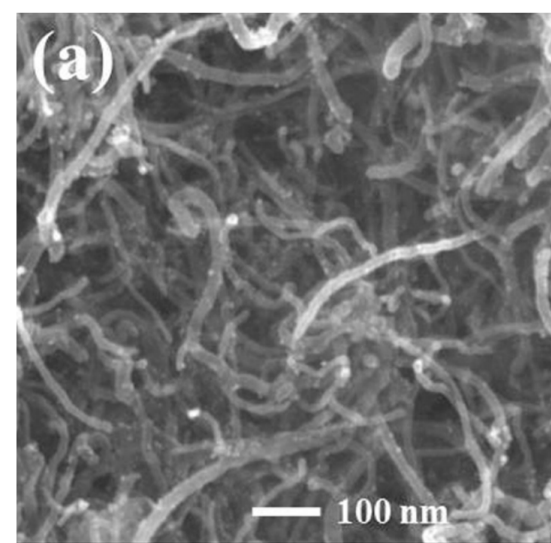

(a) FE-SEM image

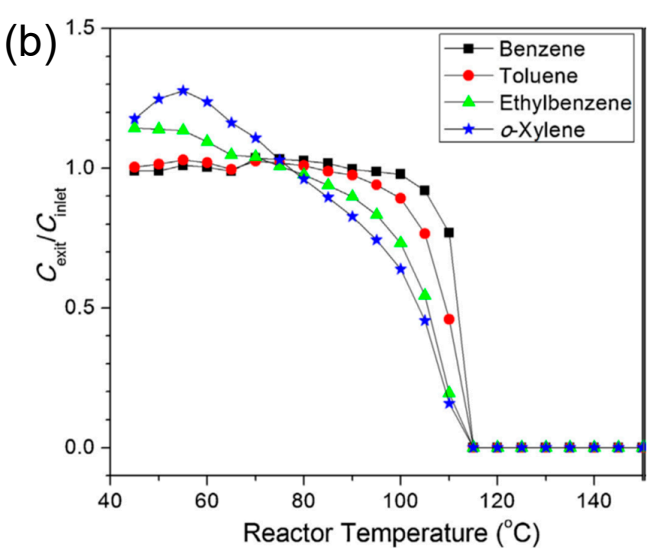

(b) Catalytic oxidation of BTEX mixture

Figure 12. (a) Field emission scanning electron microscopy image and (b) catalytic oxidation of BTEX mixture as a function of reactor temperature over $30 \mathrm{wt} \% \mathrm{Pt} / \mathrm{CNT}$ catalyst [56]. (adapted from [56], with permission from Elsevier, 2019).

\subsubsection{Graphene and Graphene Oxide (GO)}

Graphene and graphene oxide (GO) have been considered as a proficient matrix for sorption gaseous pollutants due to their advanced properties including facile synthesis method, high surface area, robust pore structure, lightweight, high chemical stability, and high thermal stability [71]. In recent years, great effort has been put into combining graphene/GO with various metal oxides (including $\mathrm{TiO}_{2}, \mathrm{WO}_{3}, \mathrm{SnO}_{2}$ and $\mathrm{CO}_{3} \mathrm{O}_{4}$ etc.) to improve the efficiency of VOCs' removal. Even with unique structural and electronic properties, the metal oxide (e.g., $\mathrm{TiO}_{2}$ /graphene) was found to be the same in essence as other $\mathrm{TiO}_{2}$ /carbon (carbon nanotubes, fullerenes, and activated carbon) composite materials with regards to the enhancement of photocatalytic activity of $\mathrm{TiO}_{2}$ [57]. Since GO can be readily prepared from low-priced graphite materials on a huge scale, the usage of GO-based hybrid multifunctional materials should be much more profitable than that of other expensive nanomaterials such as functionalized carbon nanotubes [71].

Zhang et al. [57] prepared the nanocomposites of $\mathrm{TiO}_{2} /$ graphene via a facile hydrothermal reaction of graphene oxide and $\mathrm{TiO}_{2}$ in an ethanol water solvent. This nanocomposite showed much higher photocatalytic activity and stability than bare $\mathrm{TiO}_{2}$ toward the gas-phase degradation of benzene, and the higher weight ratio in $\mathrm{TiO}_{2} /$ graphene will decrease the photocatalytic activity. The photocatalytic efficiency can be strongly affected by the structure of graphene-based composites. Roso et al. [58] compared the performances of three graphene-based co-catalysts (graphene oxide, reduced graphene oxide, and few-layer graphene) on methanol gas-phase photooxidation. Among them, the reduced graphene oxide gave the best performance on degrading methanol with a higher rate.

\section{Applications on Buildings}

Photocatalysts can be applied on construction materials; their superior photoactivated properties can efficiently reduce or abate the harmful VOCs under UV light irradiation. These materials allowed both to degrade polluting compounds at the materials surface and to decrease maintenance costs thanks to their self-cleaning properties. As a main function for the self-cleaning applications, these materials such as $\mathrm{TiO}_{2}$ were coated on the surface or mixed with the building materials including glass, mortars, stone [72], asphalt and concrete [73,74], etc. Table 2 summarized the common applications of photocatalytic materials for VOC removal on buildings. 
Table 2. Applications of photocatalytic materials for VOC removal on buildings.

\begin{tabular}{|c|c|c|c|c|c|c|c|}
\hline No. & Catalytic & Applications & Materials & Comparison \& Experiments & Pollutants & Performance & Ref. \\
\hline 1 & Thermal & $\begin{array}{l}\text { Indoor air } \\
\text { purification }\end{array}$ & $\mathrm{Pt} / \mathrm{ZnO} / \mathrm{SiC}$ & $\begin{array}{l}\text { Toluene concentration: } 100 \sim 500 \mathrm{ppm} \\
\text { Loading of Pt nanoparticles:0.030 wt } \% \\
\text { (Pt/ZnO/SiC) } \sim 0.017 \mathrm{wt} \%(\mathrm{Pt} / \mathrm{SiC})\end{array}$ & Toluene & $\begin{array}{l}\text { Toluene was used as a model volatile organic } \\
\text { compound and reached complete conversion of up } \\
\text { to } 100 \% \text { over the porous tubular } \mathrm{Pt} / \mathrm{ZnO} / \mathrm{SiC} \\
\text { material at a filtration velocity of } 0.72 \mathrm{~m} / \mathrm{min} \text { within } \\
240 \mathrm{~h} \text { at } 210^{\circ} \mathrm{C} \text { maintained within } 24 \mathrm{~h}\end{array}$ & [75] \\
\hline 2 & Photo- & $\begin{array}{l}\text { Indoor air } \\
\text { purification }\end{array}$ & $\begin{array}{l}\text { Glass fiber tissue } \\
\text { supported } \mathrm{TiO}_{2}\end{array}$ & $\begin{array}{l}\text { Inlet pollutant concentrations }(25-300 \mathrm{mg} \\
\left.\mathrm{m}^{-3}\right) \text {, flow rates }\left(2-8 \mathrm{~m}^{3} \mathrm{~h}^{-1}\right) \text {, relative } \\
\text { humidity of effluent }(5,30,50 \text { and } 90 \%) \text {, } \\
\text { input of the plasma discharge }(9-21 \mathrm{kV})\end{array}$ & Trichloromethane $\left(\mathrm{CHCl}_{3}\right)$ & $\begin{array}{l}\text { Combination of plasma DBD and photocatalysis } \\
\text { enhances the removal efficiency }\end{array}$ & [76] \\
\hline 3 & Photo- & $\begin{array}{l}\text { Indoor air } \\
\text { purification }\end{array}$ & $\mathrm{Ln}^{3+}-\mathrm{TiO}_{2}$ & $\begin{array}{c}\mathrm{La}^{3+}-\mathrm{TiO}_{2} \text { and } \mathrm{Nd}^{3+}-\mathrm{TiO}_{2} \\
\text { Lanthanide ion dosage of } 0.7 \%, 1.2 \%, 1.6 \% \\
\text { and } 2.0 \%\end{array}$ & $\begin{array}{l}\text { benzene, toluene, } \\
\text { ethylbenzene and } \\
\text { o-xylene (BTEX) }\end{array}$ & $\begin{array}{l}\text { Highest adsorption ability: } 0.7 \% \mathrm{Ln}^{3+}-\mathrm{TiO}_{2} \\
\text { catalysts. } \\
\mathrm{TiO}_{2} \text { photocatalytic efficiency with the lanthanide } \\
\text { ion doping was remarkably enhanced by BTEX } \\
\text { removal. The } 1.2 \% \mathrm{Ln}^{3+}-\mathrm{TiO}_{2} \text { catalysts achieved the } \\
\text { highest photocatalytic activity. } \\
\text { Residence time: } 72 \mathrm{~s} \text { using } 1.2 \% \mathrm{La}^{3+}-\mathrm{TiO}_{2} \text { catalyst }\end{array}$ & [77] \\
\hline 4 & Photo- & Coating & $\mathrm{TiO}_{2}$ thin films & $\begin{array}{l}\text { Commercial glasses: Pilkington Activ } \\
\text { Blue PAB) and Pilkington Activ }{ }^{\mathrm{TM}} \text { Clear } \\
\text { (PAC). }\end{array}$ & 2-propanol & $\begin{array}{l}\text { For the 2-propanol oxidation, } \mathrm{PAC} \text { was found to be } \\
\text { more active under } \mathrm{UV} \text { light due to the larger surface } \\
\text { area and higher } \mathrm{TiO}_{2} \text { particle concentration. }\end{array}$ & [67] \\
\hline 5 & Photo- & Coating & $\begin{array}{l}\mathrm{TiO}_{2} \text { coated on } \\
\text { fiberglass fibers }\end{array}$ & $\begin{array}{l}\mathrm{TiO}_{2} \text { coated on carbon cloth fibres, a pilot } \\
\text { duct system for experiment }\end{array}$ & polytetrafluoroethylene & $\begin{array}{l}\text { The single-pass removal efficiency ranks: alcohols > } \\
\text { ketones > aromatics > alkanes. }\end{array}$ & [69] \\
\hline 6 & Photo- & Coating & $\mathrm{TiO}_{2}$ & $\begin{array}{l}\text { single-layer coating \& multilayer } \mathrm{TiO}_{2} \\
\text { coating }\end{array}$ & rhodamine B & $\begin{array}{l}\text { Degrading self-cleaning ability of analysed coatings } \\
\text { caused by ageing processes, and no significant } \\
\text { difference between single-layer and multilayer } \\
\text { coatings in the long-term }\end{array}$ & [63] \\
\hline 7 & Photo- & Paint & $\begin{array}{l}\text { Three self-cleaning } \\
\text { photocatalytic } \\
\text { paints }\end{array}$ & $\begin{array}{l}\text { Three white commercial photocatalytic } \\
\text { paints; expose to UVC lamp, Xenon lamp, } \\
\text { LED and fluorescent lamps for } 10 \mathrm{~h}\end{array}$ & $\begin{array}{l}\text { methyl red, methylene } \\
\text { blue }\end{array}$ & Limited photocatalytic action under visible light & [74] \\
\hline 8 & Photo- & Paint & $\begin{array}{l}\text { commercial } \\
\text { AEROXIDE_TiO } \\
\text { P25 powder }\end{array}$ & Matrix with nitric acid and $\mathrm{H}_{2} \mathrm{SO}_{4}$ & rhodamine $b$ & $\begin{array}{l}\text { Nitric acid causes a decrease in crystallinity and } \\
\text { photocatalytic activity, which drops by almost } 20 \% \text {; } \\
\mathrm{H}_{2} \mathrm{SO}_{4} \text { the best candidate for } \mathrm{TiO}_{2} \text { nanoparticles } \\
\text { acid treatment }\end{array}$ & [75] \\
\hline 9 & Photo- & Paint & $\mathrm{TiO}_{2}$ microspheres & commercial $\mathrm{TiO}_{2}$ particles $\mathrm{P} 25$ & methylene blue solution & $\mathrm{MTiO}_{2}$ : more stable and better photoactivity & [73] \\
\hline
\end{tabular}


Table 2. Cont

\begin{tabular}{|c|c|c|c|c|c|c|c|}
\hline No. & Catalytic & Applications & Materials & Comparison \& Experiments & Pollutants & Performance & Ref. \\
\hline 10 & Photo- & Paint & $\mathrm{TiO}_{2}$ & $\begin{array}{l}5 \% \mathrm{P}^{25}-\mathrm{TiO}_{2} \text {-intermixed and dip-coated } \\
\text { SCAM samples }\end{array}$ & rhodamine $b$ & $\begin{array}{l}\mathrm{TiO}_{2} / \mathrm{SCAM} \text { : high self-cleaning ability and a robust } \\
\text { weathering resistance under UV-A and visible light } \\
\text { irradiations. }\end{array}$ & [71] \\
\hline 11 & Photo- & Paint & $\begin{array}{l}\mathrm{TiO}_{2} \text { coating } \\
\text { (PC-S7, Cristal } \\
\text { Active) }\end{array}$ & $\begin{array}{c}\mathrm{TiO}_{2}(\mathrm{P} 25) \text { intermixed nanopowder. } \\
\text { Experiments: air purifying (indicated by } \\
\mathrm{NO}_{\mathrm{x}} \text { removal) and self-cleaning (indicated } \\
\text { by Rhodamine b removal). }\end{array}$ & $\begin{array}{l}\text { Rhodamine b } \\
\mathrm{NO}_{\mathrm{x}}\end{array}$ & $\begin{array}{l}\mathrm{TiO}_{2} \text { coating on mortar shows better photocatalytic } \\
\text { performances than } \mathrm{TiO}_{2} \text { intermixed samples on air } \\
\text { purifying and self-cleaning properties under both } \\
\text { UV-A and visible light (VL) irradiation conditions. }\end{array}$ & [70] \\
\hline 12 & Photo- & Paint & $\mathrm{TiO}_{2} \mathrm{P} 25$ & $\begin{array}{c}\mathrm{ZnO} \\
\text { Experiments: Paints were exposed to } \\
\text { simulated weathering tests in a QUV panel }\end{array}$ & dye Acid Orange 7 & $\begin{array}{l}\text { Photocatalytic activity of } \mathrm{TiO}_{2} \text { increases with } \\
\text { weathering time. } \mathrm{ZnO} \text { : significantly higher } \\
\text { photocatalytic activity for initial photoactivity of the } \\
\text { unweathered paints but decreased after weathering. }\end{array}$ & [72] \\
\hline 13 & Photo- & Mortar & $\begin{array}{c}\text { Mortars } \\
\text { containing } \mathrm{TiO}_{2} \\
\text { and iron oxide } \\
\text { pigments }\end{array}$ & $\begin{array}{l}\text { Atmospheric exposure tests and } \\
\text { photocatalytic degradation tests were } \\
\text { performed. }\end{array}$ & 2-propanol & $\begin{array}{c}\text { Iron oxide pigments caused lower photocatalytic } \\
\text { activity compared to white mortars. } \\
\mathrm{TiO}_{2}+\text { mortars has lower soiling in atmospheric } \\
\text { exposure }\end{array}$ & [76] \\
\hline
\end{tabular}




\subsection{Indoor Air Treatment}

Indoor air treatment can be used to filter the VOCs from the air to maintain a good quality of air. The filter can be coated with nanomaterials to achieve a better performance for VOCs oxidation. Li et al. [75] prepared a novel $\mathrm{Pt} / \mathrm{ZnO} / \mathrm{SiC}$ filter for the oxidation of toluene; the $\mathrm{ZnO}$ coating can disperse Pt nanoparticles and significantly enhance the photocatalytic performance. This filter can achieve complete conversion of toluene at a filtration velocity of $0.72 \mathrm{~m} / \mathrm{min}$ within $240 \mathrm{~h}$ at $210^{\circ} \mathrm{C}$. $\mathrm{TiO}_{2}$ is more commonly used for application. Zadi et al. [76] evaluated the efficiency of non-thermal plasma and heterogeneous photocatalysis processes for indoor air treatment with glass fiber tissue-supported $\mathrm{TiO}_{2}$. Various impact factors were analyzed and the combination of plasma DBD and photocatalysis is proved to enhance the removal efficiency. Li et al. [77] found that the photocatalytic efficiency of the $\mathrm{TiO}_{2}$ catalysts with the lanthanide ion doping was remarkably enhanced by BTEX removal. By comparing different types of $\mathrm{Ln}^{3+}-\mathrm{TiO}_{2}\left(\mathrm{La}^{3+} / \mathrm{Nd}^{3+}-\mathrm{TiO}_{2}\right)$ with various lanthanide ion dosage, the $0.7 \% \mathrm{Ln}^{3+}-\mathrm{TiO}_{2}$ catalysts showed the highest adsorption ability, and $1.2 \% \mathrm{Ln}^{3+}-\mathrm{TiO}_{2}$ catalysts achieved the highest photocatalytic activity. Boyjoo et al. [78] also reviewed the catalyst used for air purification in 2017 and concluded that the most commonly used materials were $\mathrm{TiO}_{2}$ and $\mathrm{ZnO}$, and only very few studies were using other photocatalysts.

\subsection{Coating}

Photocatalysts have multi-function when coated on the construction materials. For example, the $\mathrm{TiO}_{2}$ coatings on the glass surface can not only degrade organic dirt and VOCs under light, but also improve the surface hydrophilicity, which can efficiently remove the dust and degraded organic dirt by rainfall [79]. Oladipo et al. [80] reported the photocatalytic activity and energy efficiency of two self-cleaning glasses, Pilkington Activ ${ }^{\mathrm{TM}}$ Blue and Pilkington Activ ${ }^{\mathrm{TM}}$ Clear. The Clear one was more active than the Blue one towards 2-propanol oxidation under ultraviolet irradiation and showed the best reactivity in the degradation of pre-adsorbed stain under simulated solar irradiation. $\mathrm{TiO}_{2}-\mathrm{Coated}$ exterior paints can contribute to a 90 98\% decane degradation [81].

$\mathrm{TiO}_{2}$ can be coated to materials in air filters to enhance the photocatalytic oxidation [82]. Zhong et al. [83] compared the performances of two commercially available photocatalytic oxidation air filters, titanium dioxide $\left(\mathrm{TiO}_{2}\right)$ coated on fiberglass fibers $\left(\mathrm{TiO}_{2} / \mathrm{FGFs}\right)$ and $\mathrm{TiO}_{2}$ coated on carbon cloth fibers $\left(\mathrm{TiO}_{2} / \mathrm{CCFs}\right)$ in a pilot duct system. The single-pass removal efficiency of these air filters ranks alcohols $>$ ketones $>$ aromatics $>$ alkanes, and various influential factors were analyzed. Jiang et al. [84] coated the ceramic tiles with $\mathrm{N}, \mathrm{F}$ and Fe ions-doped $\mathrm{TiO}_{2}$ to photo-catalytically remove $\mathrm{NO}$ under visible light. Both air pollutions of inorganic NO and organic compounds can be purified by the ceramic tiles. The coating enables ceramic tiles to have enhanced photocatalytic efficiency, low water adsorption performance, good fastness, and antibacterial capability to reduce the risk of bacterial infection.

To reserve the original aesthetic features of historical and monumental architectures, Munafo et al. [72] applied anatase $\mathrm{TiO}_{2}$ colloidal suspensions via spray-coating to deposit transparent self-cleaning coatings on stones. Photocatalytic performances of $\mathrm{TiO}_{2}$-based coatings with one and three spray cycles were compared against that of the untreated travertine. The self-cleaning ability of analyzed coatings was degraded by the ageing processes till reaching low efficiency, and it shows no significant difference between single-layer and multilayer coatings in long-term use. Results seem to encourage the use of nano-structured $\mathrm{TiO}_{2}$ for preserving stone during time, while the undercoat and new and more stable colloidal $\mathrm{TiO}_{2}$ is needed.

To achieve a high photocatalytic efficiency and a robust weathering resistant ability, Guo et al. [85] applied a transparent photocatalytic coating containing $\mathrm{TiO}_{2}$ particles on the architectural mortar; its photocatalytic performances was better than the $\mathrm{TiO}_{2}$ intermixed samples on air purifying and self-cleaning properties under both UV-A and visible light irradiation conditions, and their abilities showed no obvious deterioration during a simulated facade-weathering process. 


\subsection{Paints}

The commercial $\mathrm{TiO}_{2}, \mathrm{P} 25$ (75\% anatase and 25\% rutile phases), is commonly applied in paints. Guo et al. [86] directly applied a $\mathrm{TiO}_{2}$-containing paint (clear in colour) on the surface of self-compacting architectural mortars (SCAM). The results showed that the $\mathrm{TiO}_{2}$ paint -oated SCAM sample displayed both a high photocatalytic rhodamine $\mathrm{b}$ removal ability and a robust weathering resistance under all conditions. Baudys et al. [87] investigated the photocatalytic properties of self-cleaning acrylic paint containing $\mathrm{TiO}_{2}$ and $\mathrm{ZnO}$ using Acid Orange 7 as a model compound. The photocatalytic activity of $\mathrm{TiO}_{2}$ increases with the weathering time. However, even if the initial photoactivity of the unweathered paints with $\mathrm{ZnO}$ was significantly higher, the photocatalytic activity decreased after weathering, due to the loss and/or photocorrosion of $\mathrm{ZnO}$ particles during the weathering process. Amorim et al. [88] synthesized an efficient and durable self-cleaning acrylic paint containing mesoporous $\mathrm{TiO}_{2}\left(\mathrm{MTiO}_{2}\right)$. The paint with $\mathrm{MTiO}_{2}$ incorporated showed a better photoactivity and higher durability than the reference paint with $\mathrm{P} 25$ added in the cyclic analysis, which indicated that $\mathrm{MTiO}_{2}$ microspheres can provide acrylic paint films with self-cleaning properties without severe degradation of the binder.

The self-cleaning photocatalytic paints could be designed for specific applications for outdoor or indoor environments. Most of these photocatalytic paints are based on titanium dioxide, however, the large band gap of $\mathrm{TiO}_{2}$ requires UV photons for the electrons-holes generation, which makes it difficult to be efficient in the indoor environment. Galenda et al. [89] firstly compared the photocatalytic activity tests of indoor commercial self-cleaning paints under actual indoor light. These paints contain titanium dioxide with different amounts and crystallographic forms. The results of experiments with different lights suggest that all samples are scarcely active under visible light and the pollutant probes are selectively bleached due to their sensitizing effect. Consequently, the pollutants' ability in injecting electrons in the $\mathrm{TiO}_{2}$ conduction band deeply affects their removal.

Paolini [90] propose a pre-treatment with nitric or sulfuric acid of commercial $\mathrm{TiO}_{2}$ nanopowders to prevent from aging used in coating, mortars, or paints. photocatalytic performances for experiments with various diffuse reflectance of nitric and sulfuric acid were compared. Nitric acid causes a decrease in crystallinity and photocatalytic activity, which drops by almost $20 \%$; and sulfuric acid is the best candidate for $\mathrm{TiO}_{2}$ nanoparticles acid treatment with the aim of improving both their reflectance in a wavelength region unaffected by aging and sustaining their photocatalytic activity over time.

\subsection{Construction Materials}

Diamanti et al. [91] investigated the photocatalytic and self-cleaning activity of colored mortars containing $\mathrm{TiO}_{2}$, and its possible interaction with iron oxide pigments, which are commonly added to the mixture in the production of colored mortars. Because of the self-cleaning characteristics, $\mathrm{TiO}_{2}$ containing mortars have lower soiling in atmospheric exposure. However, the Iron oxide pigments caused lower photocatalytic activity compared to white mortars. Nath et al. [92] reviewed the photocatalysts used in concrete and found that majority of the work in concrete adopted $\mathrm{TiO}_{2}$ as the photocatalyst. They also regarded the semiconductor oxide $\mathrm{LiNbO}_{3}$, which has been used in electronic instruments to replace $\mathrm{TiO}_{2}$ for artificial photosynthesis, as a promising and relatively new approach to be used in future concrete.

For the applications of photocatalysts on buildings, it is clear that the photocatalyst $\mathrm{TiO}_{2}$ dominates the application market, and very few applications adopt other catalysts such as $\mathrm{ZnO}$. Due to its low cost, high chemical stability and non-toxic properties, $\mathrm{TiO}_{2}$ has been investigated extensively and first applied to the practical applications on buildings. Since various materials have different properties, other materials will also be applied in the near future according to their characteristics.

\section{Conclusions}

Thermal catalytic and photocatalytic nanomaterials are increasingly being used as an efficient approach to remove the VOCs, and their emerging applications on building and construction materials 
are promising for their air-cleaning properties. Among these catalysts, $\mathrm{TiO}_{2}$ is the most common, economical and efficient one due to its low cost, high chemical stability, and non-toxic properties. $\mathrm{TiO}_{2}$ has been investigated for decades and dominates the applications of catalytic VOC removal on buildings. Since other thermal catalysts also showed brilliant performance and have been studied continuously, there is expected to be more applications on buildings using other emerging catalysts rather than $\mathrm{TiO}_{2}$. As the photocatalysis performances of metal oxides can be enhanced by the synergy with hybrid adsorption materials [6], more catalysts combining different nanomaterials are expected. Among various applications of catalytic nanomaterials on buildings, the approach of coatings is more efficient and prevalent compared to intermixing [85] on the removal of VOCs. In order to remove the indoor VOCs more efficiently, more researches and applications should be done to increase their efficiencies in specific conditions such as visible light.

Author Contributions: Review proposal, K.W.S.; Information collection, K.W.S. and W.L.; Developing structure, K.W.S. and W.L.; Supervision, K.W.S.; Writing-Original Draft, W.L.; Writing-Review \& Editing, K.W.S.

Funding: This research was funded by National Research Foundation (Singapore) grant number NRF2015NRF-POC001-0025 and National University of Singapore grant R-296-000-174-720.

Acknowledgments: Acknowledgement is given to Department of Building, National University of Singapore.

Conflicts of Interest: The authors declare no conflict of interest.

\section{References}

1. Spengler, J.D.; Chen, Q. Indoor air quality factors in designing a healthy building. Annu. Rev. Energy Environ. 2000, 25, 567-600. [CrossRef]

2. Jones, A.P. Indoor air quality and health. Atmos. Environ. 1999, 33, 4535-4564. [CrossRef]

3. Maroni, M.; Seifert, B.; Lindvall, T. Indoor Air Quality: A Comprehensive Reference Book; Elsevier: New York, NY, USA, 1995; Volume 3.

4. Weschler, C.J. Ozone's impact on public health: Contributions from indoor exposures to ozone and products of ozone-initiated chemistry. Environ. Health Perspect. 2006, 114, 1489-1496. [CrossRef] [PubMed]

5. Yang, C.; Miao, G.; Pi, Y.; Xia, Q.; Wu, J.; Li, Z.; Xiao, J. Abatement of various types of VOCs by adsorption/catalytic oxidation: A review. Chem. Eng. J. 2019, 370, 1128-1153. [CrossRef]

6. Li, M.; Lu, B.; Ke, Q.-F.; Guo, Y.-J.; Guo, Y.-P. Synergetic effect between adsorption and photodegradation on nanostructured $\mathrm{TiO}_{2}$ /activated carbon fiber felt porous composites for toluene removal. J. Hazard. Mater. 2017, 333, 88-98. [CrossRef] [PubMed]

7. González-García, P. Activated carbon from lignocellulosics precursors: A review of the synthesis methods, characterization techniques and applications. Renew. Sustain. Energy Rev. 2018, 82, 1393-1414. [CrossRef]

8. Spokas, K.A.; Novak, J.M.; Stewart, C.E.; Cantrell, K.B.; Uchimiya, M.; DuSaire, M.G.; Ro, K.S. Qualitative analysis of volatile organic compounds on biochar. Chemosphere 2011, 85, 869-882. [CrossRef]

9. Zhang, X.; Gao, B.; Creamer, A.E.; Cao, C.; Li, Y. Adsorption of VOCs onto engineered carbon materials: A review. J. Hazard. Mater. 2017, 338, 102-123. [CrossRef]

10. Zhang, Z.; Chen, J.; Gao, Y.; Ao, Z.; Li, G.; An, T.; Hu, Y.; Li, Y. A coupled technique to eliminate overall nonpolar and polar volatile organic compounds from paint production industry. J. Clean. Prod. 2018, 185, 266-274. [CrossRef]

11. Tompkins, D.T.; Anderson, M.A. Evaluation of Photocatalytic Air Cleaning Capability: A Literature Review $\mathcal{E}$ Engineering Analysis; ASHRAE: Atlanta, GA, USA, 2001.

12. Mo, J.; Zhang, Y.; Xu, Q.; Lamson, J.J.; Zhao, R. Photocatalytic purification of volatile organic compounds in indoor air: A literature review. Atmos. Environ. 2009, 43, 2229-2246. [CrossRef]

13. Chen, H.; Nanayakkara, C.E.; Grassian, V.H. Titanium Dioxide Photocatalysis in Atmospheric Chemistry. Chem. Rev. 2012, 112, 5919-5948. [CrossRef] [PubMed]

14. Shayegan, Z.; Lee, C.-S.; Haghighat, $\mathrm{F}$. $\mathrm{TiO}_{2}$ photocatalyst for removal of volatile organic compounds in gas phase-A review. Chem. Eng. J. 2018, 334, 2408-2439. [CrossRef]

15. Cheng, M.; Brown, S. VOCs Identified in Australian Indoor Air and Product Emission Environments. In Proceedings of the National Clean Air Conference, Beijing, China, 4-9 September 2005; pp. 23-27. 
16. Wang, S.; Ang, H.M.; Tade, M.O. Volatile organic compounds in indoor environment and photocatalytic oxidation: State of the art. Environ. Int. 2007, 33, 694-705. [CrossRef] [PubMed]

17. Kang, D.H.; Choi, D.H.; Lee, S.M.; Yeo, M.S.; Kim, K.W. Effect of bake-out on reducing VOC emissions and concentrations in a residential housing unit with a radiant floor heating system. Build. Environ. 2010, 45, 1816-1825. [CrossRef]

18. Kim, S.; Choi, Y.-K.; Park, K.-W.; Kim, J.T. Test methods and reduction of organic pollutant compound emissions from wood-based building and furniture materials. Bioresour. Technol. 2010, 101, 6562-6568. [CrossRef] [PubMed]

19. Zheng, L.; Shah, K.W. Chapter 16: Electrochromic Smart Windows for Green Building Applications. In RSC Smart Materials; Royal Society of Chemistry: London, UK, 2019; pp. 494-520.

20. Huseien, G.F.; Sam, A.R.M.; Shah, K.W.; Asaad, M.A.; Tahir, M.M.; Mirza, J. Properties of ceramic tile waste based alkali-activated mortars incorporating GBFS and fly ash. Constr. Build. Mater. 2019, 214, 355-368. [CrossRef]

21. Seh, Z.W.; Liu, S.; Zhang, S.Y.; Shah, K.W.; Han, M.Y. Synthesis and multiple reuse of eccentric ${\mathrm{Au} @ T i \mathrm{~T}_{2}}$ nanostructures as catalysts. Chem. Commun. 2011, 47, 6689-6691. [CrossRef]

22. Hussain, M.; Akhter, P.; Iqbal, J.; Ali, Z.; Yang, W.; Shehzad, N.; Majeed, K.; Sheikh, R.; Amjad, U.; Russo, N. VOCs photocatalytic abatement using nanostructured titania-silica catalysts. J. Environ. Chem. Eng. 2017, 5, 3100-3107. [CrossRef]

23. Singh, E.; Meyyappan, M.; Nalwa, H.S. Flexible Graphene-Based Wearable Gas and Chemical Sensors. ACS Appl. Mater. Interfaces 2017, 9, 34544-34586. [CrossRef]

24. Andre, R.S.; Sanfelice, R.C.; Pavinatto, A.; Mattoso, L.H.C.; Correa, D.S. Hybrid nanomaterials designed for volatile organic compounds sensors: A review. Mater. Des. 2018, 156, 154-166. [CrossRef]

25. Kwon, S.; Fan, M.; Cooper, A.T.; Yang, H. Photocatalytic applications of micro- and nano- $\mathrm{TiO}_{2}$ in environmental engineering. Crit. Rev. Environ. Sci. Technol. 2008, 38, 197-226. [CrossRef]

26. Tsang, C.H.A.; Li, K.; Zeng, Y.; Zhao, W.; Zhang, T.; Zhan, Y.; Xie, R.; Leung, D.Y.C.; Huang, H. Titanium oxide based photocatalytic materials development and their role of in the air pollutants degradation: Overview and forecast. Environ. Int. 2019, 125, 200-228. [CrossRef]

27. Hu, M.; Yao, Z.; Wang, X. Graphene-based nanomaterials for catalysis. Ind. Eng. Chem. Res. 2017, 56, 3477-3502. [CrossRef]

28. Pan, Y.; Yuan, X.; Jiang, L.; Yu, H.; Zhang, J.; Wang, H.; Guan, R.; Zeng, G. Recent advances in synthesis, modification and photocatalytic applications of micro/nano-structured zinc indium sulfide. Chem. Eng. J. 2018, 354, 407-431. [CrossRef]

29. Sharma, R.; Sharma, S.; Dutta, S.; Zboril, R.; Gawande, M.B. Silica-nanosphere-based organic-inorganic hybrid nanomaterials: Synthesis, functionalization and applications in catalysis. Gr. Chem. 2015, 17, 3207-3230. [CrossRef]

30. Huang, H.; Xu, Y.; Feng, Q.; Leung, D.Y. Low temperature catalytic oxidation of volatile organic compounds: A review. Catal. Sci. Technol. 2015, 5, 2649-2669. [CrossRef]

31. Pelaez, M.; Nolan, N.T.; Pillai, S.C.; Seery, M.K.; Falaras, P.; Kontos, A.G.; Dunlop, P.S.M.; Hamilton, J.W.J.; Byrne, J.A.; O'Shea, K.; et al. A review on the visible light active titanium dioxide photocatalysts for environmental applications. Appl. Catal. B Environ. 2012, 125, 331-349. [CrossRef]

32. Truppi, A.; Petronella, F.; Placido, T.; Striccoli, M.; Agostiano, A.; Curri, M.; Comparelli, R. Visible-light-active $\mathrm{TiO}_{2}$-based hybrid nanocatalysts for environmental applications. Catalysts 2017, 7, 100. [CrossRef]

33. Maira, A.J.; Yeung, K.L.; Lee, C.Y.; Yue, P.L.; Chan, C.K. Size Effects in Gas-Phase Photo-oxidation of Trichloroethylene Using Nanometer-Sized $\mathrm{TiO}_{2}$ Catalysts. J. Catal. 2000, 192, 185-196. [CrossRef]

34. Maira, A.J.; Coronado, J.M.; Augugliaro, V.; Yeung, K.L.; Conesa, J.C.; Soria, J. Fourier Transform Infrared Study of the Performance of Nanostructured $\mathrm{TiO}_{2}$ Particles for the Photocatalytic Oxidation of Gaseous Toluene. J. Catal. 2001, 202, 413-420. [CrossRef]

35. Lee, H.J.; Seo, H.O.; Kim, D.W.; Kim, K.-D.; Luo, Y.; Lim, D.C.; Ju, H.; Kim, J.W.; Lee, J.; Kim, Y.D. A high-performing nanostructured $\mathrm{TiO}_{2}$ filter for volatile organic compounds using atomic layer deposition. Chem. Commun. 2011, 47, 5605-5607. [CrossRef] [PubMed]

36. Weon, S.; Choi, W. $\mathrm{TiO}_{2}$ Nanotubes with Open Channels as Deactivation-Resistant Photocatalyst for the Degradation of Volatile Organic Compounds. Environ. Sci.Technol. 2016, 50, 2556-2563. [CrossRef] [PubMed] 
37. Weon, S.; Choi, J.; Park, T.; Choi, W. Freestanding doubly open-ended $\mathrm{TiO}_{2}$ nanotubes for efficient photocatalytic degradation of volatile organic compounds. Appl. Catal. B Environ. 2017, 205, 386-392. [CrossRef]

38. Wu, C.; Yue, Y.; Deng, X.; Hua, W.; Gao, Z. Investigation on the synergetic effect between anatase and rutile nanoparticles in gas-phase photocatalytic oxidations. Catal. Today 2004, 93-95, 863-869. [CrossRef]

39. Chen, K.; Zhu, L.; Yang, K. Tricrystalline $\mathrm{TiO}_{2}$ with enhanced photocatalytic activity and durability for removing volatile organic compounds from indoor air. J. Environ. Sci. 2015, 32, 189-195. [CrossRef] [PubMed]

40. Zhong, L.; Brancho, J.J.; Batterman, S.; Bartlett, B.M.; Godwin, C. Experimental and modeling study of visible light responsive photocatalytic oxidation (PCO) materials for toluene degradation. App. Catal. B Environ. 2017, 216, 122-132. [CrossRef]

41. Qiu, X.; Miyauchi, M.; Sunada, K.; Minoshima, M.; Liu, M.; Lu, Y.; Li, D.; Shimodaira, Y.; Hosogi, Y.; Kuroda, Y.; et al. Hybrid $\mathrm{Cu}_{\mathrm{x}} \mathrm{O} / \mathrm{TiO}_{2}$ nanocomposites as risk-reduction materials in indoor environments. ACS Nano 2012, 6, 1609-1618. [CrossRef] [PubMed]

42. Weon, S.; Kim, J.; Choi, W. Dual-components modified $\mathrm{TiO}_{2}$ with $\mathrm{Pt}$ and fluoride as deactivation-resistant photocatalyst for the degradation of volatile organic compound. Appl. Catal. B Environ. 2018, 220, 1-8. [CrossRef]

43. Li, J.J.; Cai, S.C.; Yu, E.Q.; Weng, B.; Chen, X.; Chen, J.; Jia, H.P.; Xu, Y.J. Efficient infrared light promoted degradation of volatile organic compounds over photo-thermal responsive Pt-rGO-TiO ${ }_{2}$ composites. Appl. Catal. B Environ. 2018, 233, 260-271. [CrossRef]

44. Suárez, S.; Jansson, I.; Ohtani, B.; Sánchez, B. From titania nanoparticles to decahedral anatase particles: Photocatalytic activity of $\mathrm{TiO}_{2}$ /zeolite hybrids for VOCs oxidation. Catal. Today 2019, 326, 2-7. [CrossRef]

45. Li, X.; Zhu, Z.; Zhao, Q.; Wang, L. Photocatalytic degradation of gaseous toluene over $\mathrm{ZnAl}_{2} \mathrm{O}_{4}$ prepared by different methods: A comparative study. J. Hazard. Mater. 2011, 186, 2089-2096. [CrossRef]

46. Jiang, S.; Handberg, E.S.; Liu, F.; Liao, Y.; Wang, H.; Li, Z.; Song, S. Effect of doping the nitrogen into carbon nanotubes on the activity of $\mathrm{NiO}$ catalysts for the oxidation removal of toluene. Applied Catal. B Environ. 2014, 160-161, 716-721. [CrossRef]

47. Kim, H.I.; Kim, H.N.; Weon, S.; Moon, G.H.; Kim, J.H.; Choi, W. Robust Co-catalytic performance of nanodiamonds loaded on WO3 for the decomposition of volatile organic compounds under visible light. ACS Catal. 2016, 6. [CrossRef]

48. Genuino, H.C.; Dharmarathna, S.; Njagi, E.C.; Mei, M.C.; Suib, S.L. Gas-phase total oxidation of benzene, toluene, ethylbenzene, and xylenes using shape-selective manganese oxide and copper manganese oxide catalysts. J. Phys. Chem. C 2012, 116, 12066-12078. [CrossRef]

49. Miyawaki, J.; Lee, G.H.; Yeh, J.; Shiratori, N.; Shimohara, T.; Mochida, I.; Yoon, S.H. Development of carbon-supported hybrid catalyst for clean removal of formaldehyde indoors. Catal. Today 2012, 185, $278-283$. [CrossRef]

50. Qian, X.; Yue, D.; Tian, Z.; Reng, M.; Zhu, Y.; Kan, M.; Zhang, T.; Zhao, Y. Carbon quantum dots decorated Bi2WO6 nanocomposite with enhanced photocatalytic oxidation activity for VOCs. Appl. Catal. B Environ. 2016, 193, 16-21. [CrossRef]

51. Cao, J.; Luo, B.; Lin, H.; Chen, S. Photocatalytic activity of novel AgBr/WO3 composite photocatalyst under visible light irradiation for methyl orange degradation. J. Hazard. Mater. 2011, 190, 700-706. [CrossRef]

52. Abbasi, Z.; Haghighi, M.; Fatehifar, E.; Saedy, S. Synthesis and physicochemical characterizations of nanostructured $\mathrm{Pt} / \mathrm{Al} 2 \mathrm{O} 3-\mathrm{CeO}_{2}$ catalysts for total oxidation of VOCs. J. Hazard. Mater. 2011, 186, 1445-1454. [CrossRef]

53. Chen, Z.; Mao, J.; Zhou, R. Preparation of size-controlled Pt supported on Al2O3 nanocatalysts for deep catalytic oxidation of benzene at lower temperature. Appl. Surf. Sci. 2019, 465, 15-22. [CrossRef]

54. Wang, L.; Sakurai, M.; Kameyama, H. Study of catalytic decomposition of formaldehyde on $\mathrm{Pt} / \mathrm{TiO}_{2}$ alumite catalyst at ambient temperature. J. Hazard. Mater. 2009, 167, 399-405. [CrossRef]

55. Schick, L.; Sanchis, R.; González-Alfaro, V.; Agouram, S.; López, J.M.; Torrente-Murciano, L.; García, T.; Solsona, B. Size-activity relationship of iridium particles supported on silica for the total oxidation of volatile organic compounds (VOCs). Chem. Eng. J. 2019, 366, 100-111. [CrossRef]

56. Joung, H.-J.; Kim, J.-H.; Oh, J.-S.; You, D.-W.; Park, H.-O.; Jung, K.-W. Catalytic oxidation of VOCs over CNT-supported platinum nanoparticles. Appl. Surf. Sci. 2014, 290, 267-273. [CrossRef] 
57. Zhang, Y.; Tang, Z.-R.; Fu, X.; Xu, Y.-J. TiO $2-$ Graphene Nanocomposites for Gas-Phase Photocatalytic Degradation of Volatile Aromatic Pollutant: $\mathrm{Is}_{\mathrm{TiO}_{2}}-$ Graphene Truly Different from Other $\mathrm{TiO}_{2}-\mathrm{Carbon}$ Composite Materials? ACS Nano 2010, 4, 7303-7314. [CrossRef]

58. Roso, M.; Boaretti, C.; Pelizzo, M.G.; Lauria, A.; Modesti, M.; Lorenzetti, A. Nanostructured Photocatalysts Based on Different Oxidized Graphenes for VOCs Removal. Ind. Eng. Chem. Resour. 2017, 56, 9980-9992. [CrossRef]

59. Demeestere, K.; Dewulf, J.; Van Langenhove, H. Heterogeneous Photocatalysis as an Advanced Oxidation Process for the Abatement of Chlorinated, Monocyclic Aromatic and Sulfurous Volatile Organic Compounds in Air: State of the Art. Crit. Rev Environ. Sci. Technol. 2007, 37, 489-538. [CrossRef]

60. Fujishima, A.; Honda, K. Electrochemical Photolysis of Water at a Semiconductor Electrode. Nature 1972, 238, 37-38. [CrossRef] [PubMed]

61. Di Paola, A.; Bellardita, M.; Palmisano, L. Brookite, the least known $\mathrm{TiO}_{2}$ photocatalyst. Catalysts 2013, 3, 36-73. [CrossRef]

62. Monai, M.; Montini, T.; Fornasiero, P. Brookite: Nothing New under the Sun? Catalysts 2017, 7, 304. [CrossRef]

63. Jo, W.-K.; Kim, J.-T. Application of visible-light photocatalysis with nitrogen-doped or unmodified titanium dioxide for control of indoor-level volatile organic compounds. J. Hazard. Mater. 2009, 164, 360-366. [CrossRef]

64. Elfalleh, W.; Assadi, A.A.; Bouzaza, A.; Wolbert, D.; Kiwi, J.; Rtimi, S. Innovative and stable $\mathrm{TiO}_{2}$ supported catalytic surfaces removing aldehydes under UV-light irradiation. J. Photochem. Photobiol. A Chem. 2017, 343, 96-102. [CrossRef]

65. Assadi, A.A.; Bouzaza, A.; Wolbert, D.; Petit, P. Isovaleraldehyde elimination by $\mathrm{UV} / \mathrm{TiO}_{2}$ photocatalysis: Comparative study of the process at different reactors configurations and scales. Environ. Sci. Pollut. Res. 2014, 21, 11178-11188. [CrossRef] [PubMed]

66. Palau, J.; Assadi, A.A.; Penya-Roja, J.; Bouzaza, A.; Wolbert, D.; Martínez-Soria, V. Isovaleraldehyde degradation using UV photocatalytic and dielectric barrier discharge reactors, and their combinations. J. Photochem. Photobiol. A Chemis. 2015, 299, 110-117. [CrossRef]

67. Azzouz, I.; Habba, Y.G.; Capochichi-Gnambodoe, M.; Marty, F.; Vial, J.; Leprince-Wang, Y.; Bourouina, T. Zinc oxide nano-enabled microfluidic reactor for water purification and its applicability to volatile organic compounds. Microsyst. Nanoengin. 2018, 4. [CrossRef]

68. Chen, J.; Chen, X.; Yan, D.; Jiang, M.; Xu, W.; Yu, H.; Jia, H. A facile strategy of enhancing interaction between cerium and manganese oxides for catalytic removal of gaseous organic contaminants. Appl. Catal. B Environ. 2019, 250, 396-407. [CrossRef]

69. Zhao, Q.; Liu, Q.; Song, C.; Ji, N.; Ma, D.; Lu, X. Enhanced catalytic performance for VOCs oxidation on the CoAlO oxides by KMnO4 doped on facile synthesis. Chemosphere 2019, 218, 895-906. [CrossRef] [PubMed]

70. Kobayashi, B.; Yamamoto, R.; Ohkita, H.; Mizushima, T.; Hiraishi, A.; Kakuta, N. Photocatalytic Activity of $\mathrm{AgBr}$ as an Environmental Catalyst. Top Catal. 2013, 56, 618-622. [CrossRef]

71. Samaddar, P.; Son, Y.-S.; Tsang, D.C.W.; Kim, K.-H.; Kumard, S. Progress in graphene-based materials as superior media for sensing, sorption, and separation of gaseous pollutants. Coord. Chem. Rev. 2018, 368, 93-114. [CrossRef]

72. Munafò, P.; Quagliarini, E.; Goffredo, G.B.; Bondioli, F.; Licciulli, A. Durability of nano-engineered $\mathrm{TiO}_{2}$ self-cleaning treatments on limestone. Constr. Build. Mater. 2014, 65, 218-231. [CrossRef]

73. Toro, C.; Jobson, B.T.; Haselbach, L.; Shen, S.; Chung, S.H. Photoactive roadways: Determination of CO, $\mathrm{NO}$ and VOC uptake coefficients and photolabile side product yields on $\mathrm{TiO}_{2}$ treated asphalt and concrete. Atmos. Environ. 2016, 139, 37-45. [CrossRef]

74. Huseien, G.F.; Shah, K.W.; Sam, A.R.M. Sustainability of nanomaterials based self-healing concrete: An all-inclusive insight. J. Build. Eng. 2019, 23, 155-171. [CrossRef]

75. Li, L.; Zhang, F.; Zhong, Z.; Zhu, M.; Jiang, C.; Hu, J.; Xing, W. Novel Synthesis of a High-Performance $\mathrm{Pt} / \mathrm{ZnO} / \mathrm{SiC}$ Filter for the Oxidation of Toluene. Ind. Eng. Chem. Res. 2017, 56, 13857-13865. [CrossRef]

76. Zadi, T.; Assadi, A.A.; Nasrallah, N.; Bouallouche, R.; Tri, P.N.; Bouzaza, A.; Azizi, M.M.; Maachi, R.; Wolbert, D. Treatment of hospital indoor air by a hybrid system of combined plasma with photocatalysis: Case of trichloromethane. Chem. Eng. J. 2018, 349, 276-286. [CrossRef]

77. Li, F.B.; Li, X.Z.; Ao, C.H.; Lee, S.C.; Hou, M.F. Enhanced photocatalytic degradation of VOCs using $\mathrm{Ln} 3+-\mathrm{TiO}_{2}$ catalysts for indoor air purification. Chemosphere 2005, 59, 787-800. [CrossRef] [PubMed] 
78. Boyjoo, Y.; Sun, H.; Liu, J.; Pareek, V.K.; Wang, S. A review on photocatalysis for air treatment: From catalyst development to reactor design. Chem. Eng. J. 2017, 310, 537-559. [CrossRef]

79. Chabas, A.; Lombardo, T.; Cachier, H.; Pertuisot, M.H.; Oikonomou, K.; Falcone, R.; Verità, M.; Geotti-Bianchini, F. Behaviour of self-cleaning glass in urban atmosphere. Build. Environ. 2008, 43, 2124-2131. [CrossRef]

80. Oladipo, H.; Garlisi, C.; Al-Ali, K.; Azar, E.; Palmisano, G. Combined photocatalytic properties and energy efficiency via multifunctional glass. J. Environ. Chem. Eng. 2019, 7. [CrossRef]

81. Monteiro, R.A.R.; Lopes, F.V.S.; Silva, A.M.T.; Ângelo, J.; Silva, G.V.; Mendes, A.M.; Boaventura, R.A.R.; Vilar, V.J.P. Are $\mathrm{TiO}_{2}$-based exterior paints useful catalysts for gas-phase photooxidation processes? A case study on n-decane abatement for air detoxification. Appl. Catal. B Environ. 2014, 147, 988-999. [CrossRef]

82. Martinez, T.; Bertron, A.; Escadeillas, G.; Ringot, E.; Simon, V. BTEX abatement by photocatalytic $\mathrm{TiO}_{2}$-bearing coatings applied to cement mortars. Build. Environ. 2014, 71, 186-192. [CrossRef]

83. Zhong, L.; Haghighat, F.; Lee, C.S.; Lakdawala, N. Performance of ultraviolet photocatalytic oxidation for indoor air applications: Systematic experimental evaluation. J. Hazard. Mater. 2013, 261, 130-138. [CrossRef]

84. Jiang, Q.; Qi, T.; Yang, T.; Liu, Y. Ceramic tiles for photocatalytic removal of NO in indoor and outdoor air under visible light. Build. Environ. 2019, 158, 94-103. [CrossRef]

85. Guo, M.-Z.; Maury-Ramirez, A.; Poon, C.S. Photocatalytic activities of titanium dioxide incorporated architectural mortars: Effects of weathering and activation light. Build. Environ. 2015, 94, 395-402. [CrossRef]

86. Guo, M.-Z.; Maury-Ramirez, A.; Poon, C.S. Self-cleaning ability of titanium dioxide clear paint coated architectural mortar and its potential in field application. J. Clean. Product. 2016, 112, 3583-3588. [CrossRef]

87. Baudys, M.; Krýsa, J.; Zlámal, M.; Mills, A. Weathering tests of photocatalytic facade paints containing ZnO and $\mathrm{TiO}_{2}$. Chem. Eng. J. 2015, 261, 83-87. [CrossRef]

88. Amorim, S.M.; Suave, J.; Andrade, L.; Mendes, A.M.; José, H.J.; Moreira, R.F.P.M. Towards an efficient and durable self-cleaning acrylic paint containing mesoporous $\mathrm{TiO}_{2}$ microspheres. Prog. Org. Coat. 2018, 118, 48-56. [CrossRef]

89. Galenda, A.; Visentin, F.; Gerbasi, R.; Favaro, M.; Bernardi, A.; El Habra, N. Evaluation of self-cleaning photocatalytic paints: Are they effective under actual indoor lighting systems? Appl. Catal. B Environ. 2018, 232, 194-204. [CrossRef]

90. Paolini, R.; Borroni, D.; Pedeferri, M.; Diamanti, M.V. Self-cleaning building materials: The multifaceted effects of titanium dioxide. Constr. Build. Mater. 2018, 182, 126-133. [CrossRef]

91. Diamanti, M.V.; Del Curto, B.; Ormellese, M.; Pedeferri, M. Photocatalytic and self-cleaning activity of colored mortars containing $\mathrm{TiO}_{2}$. Constr. Build. Mater. 2013, 46, 167-174. [CrossRef]

92. Nath, R.K.; Zain, M.F.M.; Jamil, M. An environment-friendly solution for indoor air purification by using renewable photocatalysts in concrete: A review. Renew. Sustain. Energy Rev. 2016, 62, 1184-1194. [CrossRef] 